\title{
Anticausatives and lability in Italian and French: a diachronic-synchronic comparative study
}

\begin{abstract}
This article explores the interplay of the event structure template of verbs with the verb's inherent meaning (the 'root') and the nature of the subject (e.g., animacy and control) in shaping the distribution of the different strategies available to mark anticausativization - the active intransitive (i.e. lability) and the reflexive (SE) - in Italian and French, both diachronically and synchronically, in light of their Latin antecedents, the $-r$ form, the reflexive and the active intransitive. It is shown that both in Italian and French SE comes to be gradually associated with verbs lexicalizing telic change, interacting with the voice domain, starting from the alternation between the reflexive and the active intransitive in Old Italian, and from the active intransitive as the sole/main anticausative strategy in Old French. The aspectual specification of verbs also affects the synchronic distribution of the anticausative strategies, with the reflexive being not only a marker of thematic reduction, but also signalling in some of its uses the presence of a final goal/result or target state in the lexical meaning of a verb, occurring with verbs lexically encoding a scalar change, either in all their uses or in some of them.
\end{abstract}

Keywords: anticausative, reflexive, lability, aspect, scalar change

\section{Introduction}

This article investigates diachronic and synchronic aspects of the morphosyntax of anticausatives in two Romance languages, Italian and French, in light of their Latin antecedents, in relation to the distribution of the different strategies available to mark anticausativization: the active intransitive (i.e. lability) and the reflexive in Italian and French, the (mediopassive) $-r$ form, the reflexive pattern and the active intransitive in Latin. The analysis focuses on the persistence of the parameters determining variability in the encoding of anticausatives in Latin - (i) aspectual (reflecting the event structure template of the verbs allowing this type of intransitive alternation), (ii) thematic (relating to the nature of the subject, i.e. its affectedness/animacy/control), (iii) lexical, resulting from the nature of the

Michela Cennamo, University of Naples Federico II, e-mail: micennam@unina.it

Ә Open Access. (C) 2021 Michela Cennamo, published by De Gruyter. @) BY-NC-ND This work is licensed under the Creative Commons Attribution-NonCommercial-NoDerivatives 4.0 International License.

https://doi.org/10.1515/9783110755657-009 
verb's inherent meaning, the lexical root (e.g., the type of change encoded) -, and on the function of the reflexive morpheme in this type of intransitive alternation. The latter is viewed as a marker of Actor suppression and/or telicity, according to the language and the diachronic stage of the change.

The discussion is organized as follows. Section 2 provides the theoretical background on the notion of anticausativization. Section 3 illustrates diachronic aspects of the anticausative alternation in Latin and two of its Romance continuants, Italian and French. Section 4 describes the synchronic distribution of the anticausative strategies in Italian and French. Section 5 shows the relevance of a scale-based classification of verbs for a better understanding of the diachrony of anticausativization in the languages investigated, as well as of the synchronic distribution of the labile and reflexive strategies. Finally, section 6 draws the conclusions. ${ }^{1}$

\section{The anticausative alternation: its encoding and semantic constraints}

In the anticausative alternation the original inanimate object (i.e. the Undergoer) ${ }^{2}$ of a transitive pattern occurs as subject and the eventuality described by

\footnotetext{
1 Earlier versions of the present work were presented at the Cambridge Workshop on Voice, Cambridge, 22 - 24 May 2017, at the 50th Annual Meeting of the Societas Linguistica Europaea, Zurich, 10-13 September 2017, at the Institut National des Langues et Civilisations Orientales, Paris, 18 May 2018 and at the Workshop The Shaping of Transitivity and Argument Structure: Theoretical and Empirical Perspectives, Pavia, 25-27 October 2018. I wish to thank the audiences, in particular Delia Bentley, Francesco Ciconte, Carmen Dobrovie-Sorin, Rita Manzini and Alexandru Mardale for their insightful questions. Thanks are also due to Steffen Heidinger and two anonymous reviewers for most helpful comments on an earlier draft of this article. They all contributed to refine my arguments and to improve my analysis. All shortcomings and misinterpretations are, of course, mine.

The following abbreviations are used (partly in accordance with the Leipzig rules): $\mathrm{ABL}=$ ablative; ACC = accusative; $\mathrm{F}$ = feminine; FUT = future; $\mathrm{IMPF}=$ imperfect; $\mathrm{IND}=$ indicative; $\mathrm{INF}=$ infinitive; $\mathrm{M}=$ masculine; $\mathrm{MPASS}=$ mediopassive; $\mathrm{N}=$ neuter; $\mathrm{NOM}=$ nominative; $\mathrm{PL}=$ plural; $\mathrm{PP}$ =past participle; $\mathrm{PRF}=$ perfect; $\mathrm{PRS}=$ present PTCP = participle; $\mathrm{PST}$ = past tense; $\mathrm{RFL}=$ reflexive; SBJV = subjunctive; $\mathrm{SG}=$ singular.

2 Actor and Undergoer are syntactico-semantic categories, acting as the interface between thematic and syntactic relations, subsuming the different thematic relations of a verb's argument. More specifically, Actor is the generalized Agent-type argument (e.g. Agent, Effector, Instrument, Experiencer) and Undergoer is the generalized Patient-like argument (e.g. Patient, Theme, Experiencer) (Van Valin and La Polla 1997: 141; Van Valin 2005: 60-67).
} 
the verb is presented as occurring spontaneously (Haspelmath 1993, 2016). The spontaneous manifestation of an eventuality and its related feature, "unspecific change of state" (Haspelmath 1987: 15), are the main semantic properties characterizing the anticausative pattern (see also Haspelmath 2016 for a formalization of this notion within the "spontaneity scale"). Only transitive, lexically causative verbs denoting events which may come about spontaneously, without a wilful animate causer, thus most typically lexicalizing a final goal/result state may occur in the anticausative alternation (Haspelmath 1987: 15; Levin and Rappaport Hovav 1995: 102). Therefore, verbs including a manner component in their root, denoting for instance "specific instruments or methods" (Haspelmath 1993: 93) (e.g. bite, cut, dig, paint . . . ) (Haspelmath 1987: 15, 1993: 94), are excluded from this type of construction (Rappaport Hovav and Levin 2010). An additional semantic characteristic is the thematic underspecification of the causer: verbs with a thematically specified subject (i.e. an agent), such as the English assassinate, do not allow anticausativization, unlike break, open, whose subject has a lower degree of thematic specification, since it may also be instantiated by an instrument and a natural force, and which, by contrast, undergo the anticausative alternation (see Koontz-Garboden 2009: 80-90, also for a discussion of counterexamples to this generalization; Beavers and Koontz-Garboden 2012; Levin 2017, among others).

Depending on the perspective taken, the (unexpressed) Actor is viewed either as both syntactically and semantically suppressed (Haspelmath 1987: 7), or as lacking only at the level of argument structure (i.e. the lexical syntactic representation), while retained in the lexical semantic representation (Levin and Rappaport Hovav 1995: 84; Bentley 2006: 126-131; Schäfer 2008, 2009; KoontzGarboden 2009; Alexiadou 2010; Heidinger 2015, 2019; Alexiadou, Anagnostopoulou and Schäfer 2015; Haspelmath 2016 and further references therein).

As for the encoding of this alternation, as well-known and thoroughly investigated in the literature, the anticausative pattern may be either morphologically unmarked, so-called 'lability', as in (1a), or both morphologically unmarked and marked, as in (1b-c) for German and in (1d-e) for French, signalled, in the marked form, by a dedicated morpheme, e.g., the reflexive marker in (1c) and (1e). The distribution of the two strategies varies across languages, often reflecting the diachronic stage(s) investigated (Lazzeroni 2009; Heidinger 2010, 2014 for French; Cennamo 2012 for Italian; Cennamo, Ciconte and Andriani 2020 for some early Italo-Romance varieties, among others): 
(1) a. The window shattered (<John/the stone shattered the window) (unmarked)

b. Das Segel zerriss

the sail tear.PST.3SG

'The sail tore.'

(Schäfer 2008: 11)

c. Die Tür öffnete sich (marked)

the door open.PST.3SG RFL

'The door opened.'

d. Le ciment a durci (unmarked)

the cement have.PRS.3sG harden.PTCP

'The cement hardened.'

e. Le vase (se) casse (optionally marked)

the vase RFL break.PRS.IND.3SG

'The vase breaks.'

In several languages the core of the category is instantiated by verbs lexicalizing a final goal/result state (i.e. achievements/accomplishments) (Levin and Rappaport Hovav 1995: 93, among others), ${ }^{3}$ as illustrated in (1a) for English, (1b) for German and (2a) for Italian. This pattern, however, may occur also with atelic eventualities, as with (continuation of) activity verbs and states in Italian and French, exemplified in (2b) for Italian and (2c) for both Italian and French (cf. also Cennamo 1995: 92-99; Cennamo and Jezek 2011):

(2) a. Lo specchio si $\grave{e}$

the mirror RFL be.PRS.IND.3SG 'The mirror smashed.'

b. Il brutto tempo è

The bad weather be.PRS.IND continue.PST.PTCP.M.SG

per tutta la week

for whole the settimana

'The bad weather has continued for the whole week.'

\footnotetext{
3 I follow the Vendler (1967)/Dowty (1979) classification of verbs/predicates according to their temporal characteristics. Accomplishments are durative dynamic predicates with an inherent endpoint (i.e. telic); achievements are dynamic, non-durative predicates denoting an instantaneous (i.e. punctual) event with an inherent endpoint; activities are dynamic, durative predicates lacking an inherent endpoint; states are non-dynamic predicates involving no change (cf. Levin and Rappaport Hovav 2005: 88-105, among others, and references therein).
} 


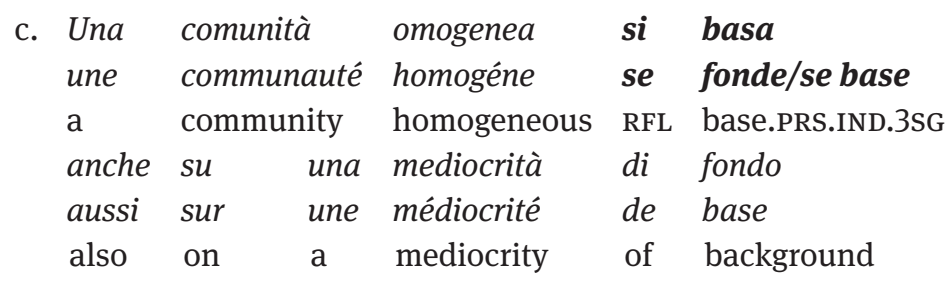

'A homogeneous community is based also on some sort of underlying mediocrity.'

\section{Diachronic paths in anticausativization}

\subsection{Latin antecedents of Romance anticausatives: synchronic and diachronic aspects}

In Latin, three strategies were available for the encoding of this type of intransitive alternation: (i) the mediopassive $-r$ form, ${ }^{4}$ (ii) the reflexive pattern, $s e+$ verb in the active voice, (iii), the active intransitive (i.e. lability) (Feltenius 1977; Cennamo 1998, 2019; Adams 2013: 686-711; Gianollo 2014; Cennamo, Eythórsson and Barðdal 2015).

The mediopassive $-r$ form is attested throughout the history of Latin, with all verb classes allowing the anticausative alternation: achievements (3a), accomplishments (3b), gradual completion verbs (i.e. verbs denoting the gradual approximation to a terminal point along a scale, which may not be attained; Bertinetto and Squartini 1995:12-13), also referred to in the literature as degree achievements (Hay, Kennedy and Levin 1999), e.g. minuere 'to decrease' (3c) and activities (3d). The possible ambiguity between an anticausative and a passive reading was resolved only by the context, as shown in (3d):
(3) a. frangitur
aestus
breaks.MPASS.PRS.IND.3SG tide.NOM
'The rolling tide breaks.'
(Lucr. De Rer. Nat. 6, 121)

\footnotetext{
4 Although it gets used as such in Latin, the mediopassive character of the Indo-European $-r$ ending is by no means certain. For instance, in Vedic it appears not only in the mediopassive, but also in the form-ur, as an active ending. It also turns up as such in Sanskrit (cf. Kuryłowicz 1964: 60-61, 65 ). In Latin the $-r$ ending is employed for different types of intransitive patterns, including middles, anticausatives, passives, and impersonals (cf. Cennamo 1998: 79, 2020: 210212 and related literature).
} 
b. (humanae quae fluxae et human.NOM.PL affair.NOM.PL which.NOM.PL unstable.NOM.PL and mobiles semper in advorsa mutantur mobile.NOM.PL always in opposite.N.PL change.MPASS.PRS.IND.3PL '(Human affairs), which, unstable and fluctuating, are always changing to opposite extremes.'

(Sall. Iug. 104, 2)

c. Memoria minuitur

memory.NOM decrease.MPASS.PRS.IND.3SG

'Memory is impaired.'

(Cic. Sen. 7, 21)

d. animi... circum terram volutantur soul(M).PL around earth.ACC roll.MPASS.PRS.IND.3PL

'Souls ... whirl/are whirled around this world.'

(Cic. Rep. 6, 28)

As for the reflexive pattern, in Early and Classical Latin this construction occurs as an anticausativization strategy with achievements and accomplishments, i.e. with inherently telic verbs, lexically encoding a final goal/result or target state ${ }^{5}$ (e.g. a reversible change) (Parsons 1990: 234-235), as shown in (4a-c):

(4) a. lutamenta scindunt se

plaster(N).PL crack.PRS.IND.3PL RFL

'Plaster cracks.'

(Cat. Agr. 128)

b. brassica... commutat=que sese semper cum calore cabbage.NOM change.PRS.IND.3SG=and RFL always with heat.ABL 'Cabbage constantly changes its nature with heat.'

(Cat. Agr. 157, 1)

c. valvae se ipsae aperuerunt

door.NOM.PL RFL themselves.NOM.PL open.PRF.IND.3PL

'The doors suddenly opened of their own accord.'

(Cic. Div. 1, 34, 74)

The reflexive also seems to be preferred (to the mediopassive $-r$ form) when the subject, although inanimate, is personified, showing some degree of control,

5 Unlike result states, that "hold for ever after the culmination of the event", target states "may or may not last for a long time” (Parsons 1990: 235). 
as in (4c). The latter can be contrasted with (4a-b), where no personification is involved, and se simply marks the intransitive (anticausative) variant (Ronconi 1968: 21; Cennamo 1998; Adams 2013: 690-691).

$\mathrm{Se}+$ active verb is not attested in anticausative function with verbs of variable/ reduced telicity, e.g. gradual completion verbs ( ${ }^{*}$ irae se leniunt anger.PL RFL heal. PRS.IND.3PL 'anger abates') and with activities ( ${ }^{\star}$ saxa se volutant stones RFL roll. PRS.IND.3PL 'stones roll'), for which only the $-r$ form (3d) and the non-reflexive, labile pattern occur (5c-d) (Cennamo 1998, 2001). By contrast, the active intransitive in Early and Classical Latin is mainly found with gradual completion verbs (e.g. lenire 'to soothe', ampliare 'to enlarge', minuere 'to decrease', sedare 'to calm down') (5a-b), and, marginally, activities (e.g. quassare 'to shake', volutare 'to roll') (5c-d):

(5) a. irae

\section{leniunt}

NOM.PL soothe.PRS.IND.3PL

'Anger abates.'

(Plaut. Mil. 583)

b. tempestas sedavit

storm.NOM calm-down.PRF.IND.3SG

'The storm went down/calmed down.'

(Gell. NA 18, 12,6)

c. capitibus quassantibus

head(N).ABL shake.PRS.PTCP.ABL

'While their heads shook.' (lit. 'their heads shaking')

(Plaut. Bacch. 304)

d. confusaque verba volutant

confused.PP.N.PL=and word(N).PL roll.PRS.IND.3PL

'And confused reports flit about.'

(Ov. Met. 12,54/55)

Lability is not found in anticausative function with verbs lexically encoding a final goal/result state, i.e. achievements (e.g. rumpere 'to break', scindere 'to crack') $(6 a-c)$, the core of the category in Latin and in other languages that show this type of transitive/intransitive alternation. An exception to this tendency is instantiated by accomplishments such as aperire ‘to open’ in Early Latin, e.g. Plautus (6d). This verb, however, denotes a reversible change of state, i.e. a target state, unlike scindere 'to crack' and rumpere 'to break', which denote a non-reversible change, i.e. a result state, and which therefore lexicalize a higher degree of telicity: 


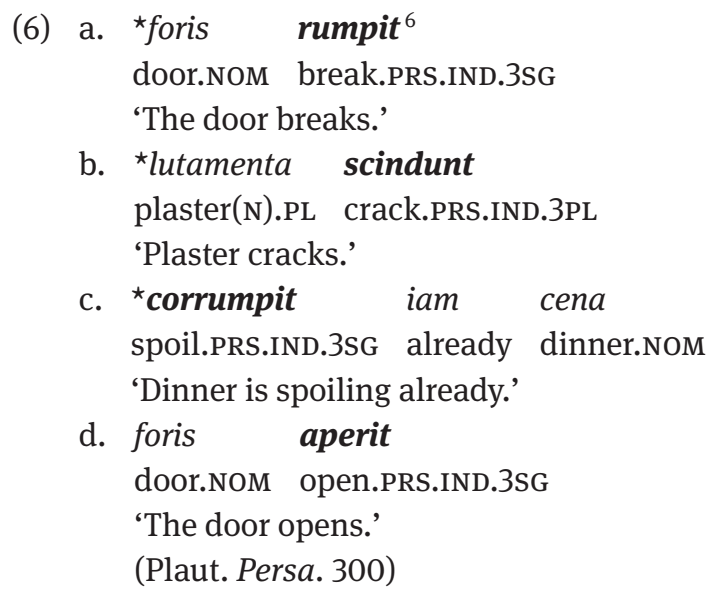

\subsubsection{Interim summary}

Summing up the main characteristics of the distribution of anticausativizaton strategies in Early and Classical Latin, it can be noted that the alternation among the different voice forms marking anticausativization is aspectually streamlined, reflecting the interplay of the event structure template of verbs with the meaning components lexicalized in their root, e.g. the type of change, reversible/target $\sim$ non-reversible/result state (Parsons 1990) (cf. also Cennamo, Eythórsson and Barðdal 2015). More specifically, (i) the $-r$ form is found with all verbs which allow anticausativization, (ii) the reflexive pattern occurs with telic verbs [ \pm punctual] (e.g. scindere 'to crack', movere 'to move', aperire 'to open', frangere 'to crack', rumpere 'to break'), (iii) the active intransitive is found with verbs which do not lexicalize the attainment of a final state, i.e. the endpoint of the process, as with gradual completion verbs (e.g. lenire 'to soothe', minuere 'to decrease', sedare 'to calm down'), albeit also attested with accomplishments denoting a target state (e.g., aperire 'to open') (Cennamo 1998, 2001) and with activities (e.g. quassare 'to shake', volutare 'to roll'). These factors interact, in the course of time, with changes in the voice system and the encoding of argument structure (Cennamo 1998, 2009; Cennamo, Eythórsson and Barðdal 2015: 693-704).

6 The asterisk $\left(^{\star}\right)$ for the Latin examples indicates that a pattern is not attested with a particular verb in the data investigated, consisting of literary and non-literary texts from III BC to IX A.D., collected from Pirson (1906), Svennung (1935), Wistrand (1942), Feltenius (1977), and the P(ackard) H(umanities) I(institute)-5 CD-ROM (see also Cennamo, Eythórsson and Barðdal 2015: 683-93, note 1 ). 


\subsubsection{Anticausatives and Transitivity in Late Latin}

In Late Latin the semantics of predicates and the inherent and relational properties of the subject no longer play a role in the morphological realization of anticausatives. Thus, the reflexive and the active intransitive also mark anticausativization with aspectual classes with which they are not found in Early and Classical Latin. The reflexive is also attested with gradual completion verbs (e.g. minuere 'to decrease') (7a), and other types of accomplishments, such as coquere 'to cook', and de-nominal verbs such as cicatricare 'to heal' (< noun cicatrix 'scar') (7c), at times alternating with the $r$-form in one and the same text, as shown in (7c-d) (Pirson 1906; Feltenius 1977):

(7) a. minuente

se morbo

decreasing.PRS.PTCP.ABL RFL disease.ABL

'When the disease is on the decline.'

(Plin. Nat. 23, 50)

b. memoria minuitur

memory.NOM decrease.MPASS.PRS.IND.3SG

'Memory is impaired/diminishes.'

(Cic. Sen. 7, 21) (Classical Latin)

c. vulnera cum se cicatricaverint

wound(N).PL when RFL heal.FUT.PRF.3PL

'When the wounds will have healed.'

(Orib. Syn. 7, $10 \mathrm{Aa}$ )

d. vulnera cicatricantur

wound(N).PL heal.MPASS.PRS.IND.3PL

'The wounds heal.'

(Orib. Syn. 7, 3)

Conversely, se + active also occurs with activities (e.g. vexare 'to oppress', servare 'to keep', excusare 'to justify, excuse') (Cennamo 1998, 2001: 238), at times with ambiguity between an anticausative and a passive interpretation, i.e. between a spontaneous vs. an induced process reading, as in (8) (Cennamo 1998, 2001, 2006):

(8) mala... toto anno servare se possunt

apple(N).PL whole.ABL year.ABL keep.INF RFL can.PRS.IND.3PL

'Apples ... can keep/be kept for the whole year.'

(Pall. De agr. 3, 25, 18; Ronconi 1968: 24)

In Late Latin the use of the active intransitive in anticausative function increases, and is well attested in 4th century technical works (e.g. veterinary texts such as 
the Mulomedicina Chironis) (Pirson 1906). This pattern also occurs with achievements (9a) and accomplishments (9b), alternating with the reflexive (9c) (Feltenius 1977: 82; Cennamo 2006: 317):
a. postea
rumpunt
dentes
afterwards break.PRS.IND.3PL tooth(F).NOM.PL
'Afterwards teeth break'
(Mul. Chir. 775, 14)
b. $u t$
confirmet
(sc. vulnus)
in_order_to heal.sBJV.PRS.3sG (wound)
'So as it (sc. the wound) heals.'
(Mul. Chir. 670)
c. donec cicatrix oculo se confirmet
till scar.NOM eye.DAT RFL heal.sBJV.PRS.3SG
'Until the scar in its eye heals.' (Mul. Chir. 76)

The three strategies appear to be fully interchangeable at this stage, occurring with all verb classes (cf. Pirson 1906; Feltenius 1977; Cennamo 1998, 2020; Cennamo, Eythórsson and Barðdal 2015, among others). Thus, in Late Latin, with clear examples from the 4th century A.D., the reflexive strategy is found not only with inherently telic verbs, i.e., achievements and accomplishments (e.g. scindere 'to crack', frangere 'to break', mutare 'to change'), but also with non-inherently telic and atelic ones (e.g. citare, provocare 'to cause', minuere 'to decrease', servare 'to keep', i.e., accomplishments of variable/reduced telicity as well as activities; Cennamo 2001). With these aspectual classes in Early and Classical Latin either only the mediopassive $r$ form (in passive function) occurred (cf. (10a) vs (10b), (10d)), or the active intransitive/the $-r$ form, in anticausative function (10c-d). If the pattern clearly marked an induced process (passive interpretation) only the $-r$ form occurred, as illustrated in (10a) and (10d) (Cennamo 1998, 2006, 2020):
(10)
a. stercora provocantur
excrement.PL cause.PRS.IND.MPASS.3PL
'Excrement is induced.'
b. *stercora se provocant excrement.PL RFL cause.PRS.IND.3SG
'`Excrement causes itself.'
c. memoria minuitur /minuit
memory.NOM decrease.MPASS.PRS.IND.3SG /PRS.IND.3SG
'Memory is impaired (lit. memory decreases).'




\section{d. mala servantur}

apple(N).PL keep.MPASS.PRS.IND.3PL

'Apples are kept.'

In some Late Latin texts (e.g. Oribasius, 6th century A.D.), the reflexive pronoun and the $-r$ form in anticausative function may co-occur, at times in one and the same sentence, with possible ambiguity between an anticausative and a passive reading, depending on the verb and on the syntactic context, as shown in (11):

\section{(11) si autem minutetur se medicamen \\ if then pulverize.MPASS.PRS.SBJV.3sG RFL drug \\ 'If then the drug pulverizes/gets pulverized.' \\ (Orib. Eup. 4, 63; Svennung 1935: 463, n. 2) (VI A.D.)}

The co-occurrence of the $-r$ form and the reflexive pronoun in (11) witnesses the functional equivalence of the two anticausativization strategies. ${ }^{7}$ This phenomenon is part and parcel of a wider change, the restructuring of the voice system taking place in Late Latin, resulting in the gradual demise of the mediopassive $-r$ form from the spoken language and its replacement by other syntactic tools in the Romance languages, the reflexive coming to cover over time the functional domains of the $-r$ suffix (passive, anticausative, middle) (cf. Cennamo 1998, 2009; Cennamo, Eythórsson and Barðdal 2015; Gianollo 2014: 990-993; Cennamo 2019 for a detailed analysis), alongside the active intransitive, as illustrated in (9a-b).

One of the outcomes of the functional equivalence among voice forms in Late Latin is the so-called deponentization, the use of the passive morphology in active function, affecting the whole verbal paradigm (Flobert 1975; Feltenius 1977), as shown in (12) for the analytic passive pattern, BE+PP, in active function in the perfect, replacing the reflexive pattern (12a) and the active intransitive (12b) (Norberg 1943: 151-174):

7 The co-occurrence of $s e$ and the $-r$ form in one and the same pattern is already found for the reflexive/middle function of these strategies in Early Latin (although its incidence needs to be investigated) as in (i), hinting at an early weakening of the $-r$ form, collocating with se to strengthen its reflexive/middle values, anticipating later examples (e.g. se iungi RFL join.MPASs. INF 'to join oneself') (Norberg 1943: 167; Cennamo 1998: 80):

(i) nemo se excalceatur

nobody.NOM RFL take-off-the-shoes.MPASS.PRS.IND.3SG

'Nobody takes off his shoes.'

(Varro. Men. 439) 


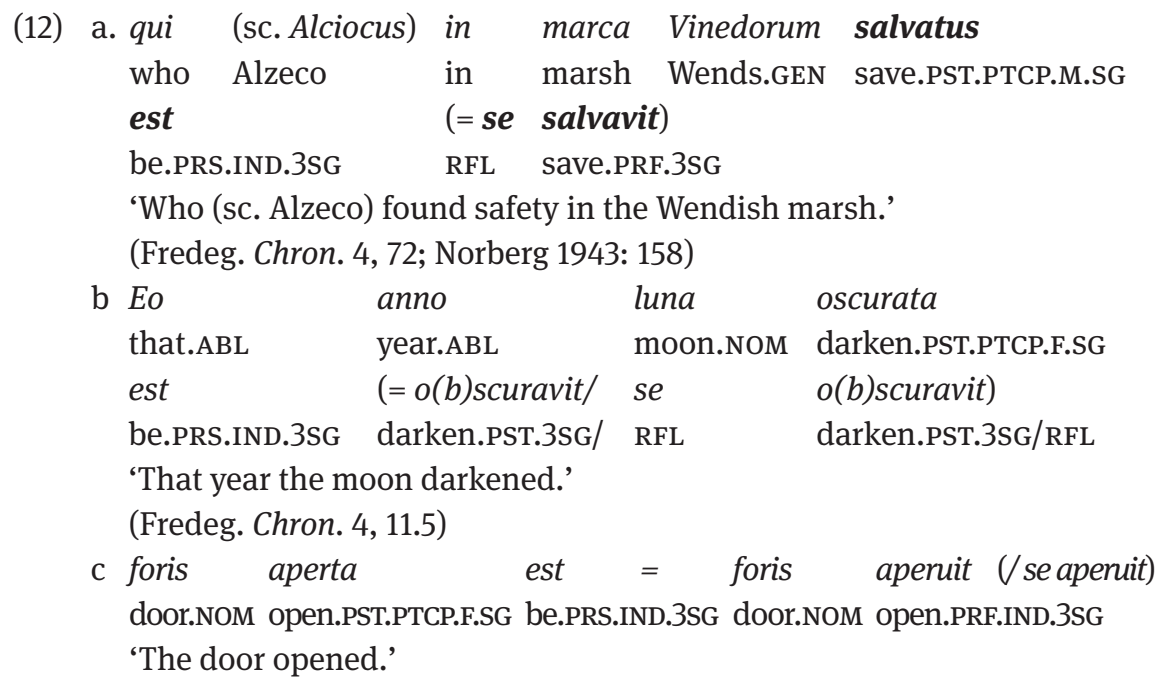

Therefore, at some point in time in Late Latin, the sequence BE+PP, formed from a telic predicate such as aperire 'to open', in a pattern such as foris aperta est (12c), could be ambiguous between a dynamic passive ("the door was opened'), a resultative stative passive ('the door has been opened'), a stative/ adjectival ('the door is open') and an anticausative reading ('the door opened'), with the analytic 'deponential'/passive perfect form (aperta est) used instead of the active perfect (aperuit), alongside the reflexive, as shown in (12c) (cf. also Cennamo 2005: 180-181, 2012: 406, note 14).

In the next sections we explore some Romance developments in the encoding of this type of intransitive alternation, starting from the functional ambiguity among voice forms illustrated above, leading to the construction exemplified in (12).

\subsection{Anticausatives in Old Italian}

The following (intertwined) paths emerge in the diachrony of anticausativization in the two Romance languages investigated, varying according to the language and the diachronic stage(s) considered: (i) the gradual emergence of aspectual notions such as telicity in determining the occurrence of/preference for the reflexive strategy with highly telic verbs (e.g. achievements and accomplishments lexicalizing a final goal/result state), (ii) the retrenching / loss subsequent remodulation of lability, witnessed by Italian and French, respec- 
tively. In both changes the aspectual properties of verbs and the meaning components lexicalized in their root (e.g. the type of change encoded) appear to play a key-role, interacting with the voice domain.

\subsubsection{The anticausative alternation in Old Italian (Old Florentine)}

In Old Florentine - the Old Tuscan vernacular (based on the 14th century language of the so-called three crowns, the great Tuscan writers Dante, Petrarca and Boccaccio), which became codified as the national standard language at the beginning of the 16th century (Maiden 1995: 5, 10; Lepschy and Lepschy 2006: 546 among others), already in the early texts (13th century) -, two strategies alternate in the marking of anticausativization in simplex tenses, the reflexive and the active intransitive, i.e. the labile form. ${ }^{8}$ They occur with the verb classes allowing this type of intransitive alternation, instantiated by achievements and accomplishments. With activity verbs, instead, the presence of the reflexive morpheme gives the pattern a passive interpretation (cf. Cennamo 2012: 405 and discussion further below). In compound tenses, the non-reflexive strategy, i.e. lability, is the form generally found, and the presence/absence of the reflexive morpheme reflects the gradual reconstitution of the tense-aspectual and voice systems consequent to the loss of the grammatical dimension of voice in the passage to Romance, described in section 3.1.2 for Late Latin in relation to the encoding of anticausativization.

The analysis reveals a higher frequency of the reflexive with verbs which lexicalize a final/result state, e.g. achievements such as spezzare 'to crack', for which the non-reflexive form is hardly attested in Old Florentine, as shown in (13b), where the only attested example of the labile form with this verb in the corpus investigated is ambiguous between an anticausative ('the spears broke') and a transitive reading ('they broke the spears'), with an unexpressed subject and le lance 'the spears' as direct object (Cennamo 2012: 406). Si generally functions as a marker of thematic reduction, but its presence also seems to be aspectually

8 The texts investigated, both literary and non-literary, taken from OVI (Opera del Vocabolario Italiano) (available at http://ovi.cnr.it), cover a time span dating from the 13th to the 15th century. They include prose, poetry, letters, volgarizzamenti (i.e. adaptations from Latin), testimonies of minute-books, deeds, contracts, transactions and court trials, in the wake of the approach by Vincent, Parry and Hastings 2004 (see also Cennamo 2012). The approach taken in the present study is qualitative, rather than quantitative, and the generalizations put forward, based on the figures obtained from the electronic search, are meant to suggest tendencies, to be tested on a wider range of lexical verbs in subsequent research. 
streamlined, since it tends to occur more prominently with verbs which lexicalize a terminal point, alternating with the active intransitive, i.e. with the labile form. Thus, fluctuation between the two strategies is found with achievements (e.g. frangere 'to smash', rompere 'to break') (13)-(15), and different types of accomplishments (e.g. aprire 'to open', mutare 'to change', cuocere 'to burn'/'cook', allagare 'to flood'), including gradual completion verbs (scurare 'to darken', seccare 'to dry', ampliare 'to enlarge', aumentare 'to increase') (16) - (17). The alternation also involves aspectual verbs (e.g. cominciare 'to begin', cessare 'to stop', continue 'to continue', denoting the beginning, termination and continuation of an activity, respectively), illustrated in (17) for continuare:

a. la spada sì si spezza presso alla the sword thus RFL break.PRS.IND.3SG near to-the punta (achievement)

tip

'The sword breaks near the tip'

(Tavola ritonda, [cap. 18 | page 71.19-20])

$\begin{array}{lllll}\text { b. si feriscono per } & \text { tale vigoria, che } \\ \text { RFL wound.PRS.IND.3PL for } & \text { such strength that } \\ \text { le lance spezzarono in many } & \text { pieces } \\ \text { the spears break.PST.3PL in più pezzi } & \end{array}$

'They wound each other fiercely, so that the spears break (lit. broke) into several pieces/so as to break the spears in several pieces' (Tavola ritonda, [cap. 18 | page 70.28])

(14) a. Come si frange il sonno how RFL break.PRS.IND.3SG the sleep

'As sleep gets interrupted'

[p. B284] (Dante. Commedia, [Purg. 17 | page B283, 40])

b. e'l mar che frange

and-the sea that break.PRS.IND.3sG

'And the sea that breaks'

(Petrarca. Canzoniere, 277, 7)

(15) a. (lo stato di Roma) quasi ogne die di (the state of Rome) almost every day of diverse maniere si muta (accomplishment)

different ways RFL change.PRS.IND.3SG

'The State of Rome changes almost every day'

(Bono Giamboni. Orosio, [L. 6, cap. 12 | page 384]a) 
b. (logiorno) poi ver' mezzo giorno... muta the day then towards noon... change.PRS.IND.3sG 'Then the day changes towards noon' (Percivalle Doria (ed. Contini) 1264 (Old Tuscan) [Parte non numerata 1 ( page 162])

(16) a. per la qual cosa la fama owing_to the which thing the fame sua s'ampliò molto (gradual completion verb) his RFL-increase.PST.3SG a_lot

'Owing to this his fame increased' (Boccaccio. Esposizioni, [par. 22 | page 692])

b. poi ampliò la fama di SantaMaria in Pruneta then increase.PST.3SG the fame of Saint Mary in Pruneto 'Then the fame of Saint Mary in Pruneto increased' (Sacch. L, 9,29; Brambilla Ageno 1964: 64)

(17) a. dalle altre due parti, onde si from-the other two parts where RFL continua la terra (aspectuals-continuation of activity) continue.PRS.IND.3SG the earth 'From the other two areas, where the earth continues' (Bono Giamboni. Orosio, [L. 1, cap. 2 | page 19])

b. In questa prima parte (il capitulo) continua in this first section the chapter continue.PRS.IND.3sG 'In the first section the chapter continues ...' (Chiose falso Boccaccio. Inf., 1375 (fior.))

With activity/process verbs such as bollire 'to boil', only the non-reflexive form is found (18a). The reflexive pattern, in fact, has a passive interpretation, as expected, since it is an activity verb. Thus, l'acqua si bolle in (18b) does not mean 'water boils' but 'water is boiled', with si signalling external causation (see also Cennamo 2012: 409):

(18) a. perocché il mosto ancora bolliva since the grape-must still boil.IMPF.IND.3SG

'Since the grape must was still boiling' (Marchionne di Coppo, Cronaca fiorentina, [Rubr. 876 | page 382]) 
b. la cui acqua si bolle in caldare

the whose water RFL boil.PRS.IND.3SG in containers

di piombo e fasse=ne sale

of lead and make.PRS.IND.3SG.RFL=of_it salt

'Whose water is boiled in three lead containers and salt is made with it.'

(Metaura d'Aristotile volgarizzata, App. B, 2, 29, page 327. 2-3)

The two strategies alternate with the verb cuocere 'to cook, burn' under its processual interpretation, ‘to burn' (19a-b). By contrast, when the verb lexicalizes a result, i.e. under the meaning 'to cook', the reflexive form occurs, as shown in (19c) (cf. also Cennamo 2012: 408; Cennamo, Ciconte and Andriani 2020: 165):

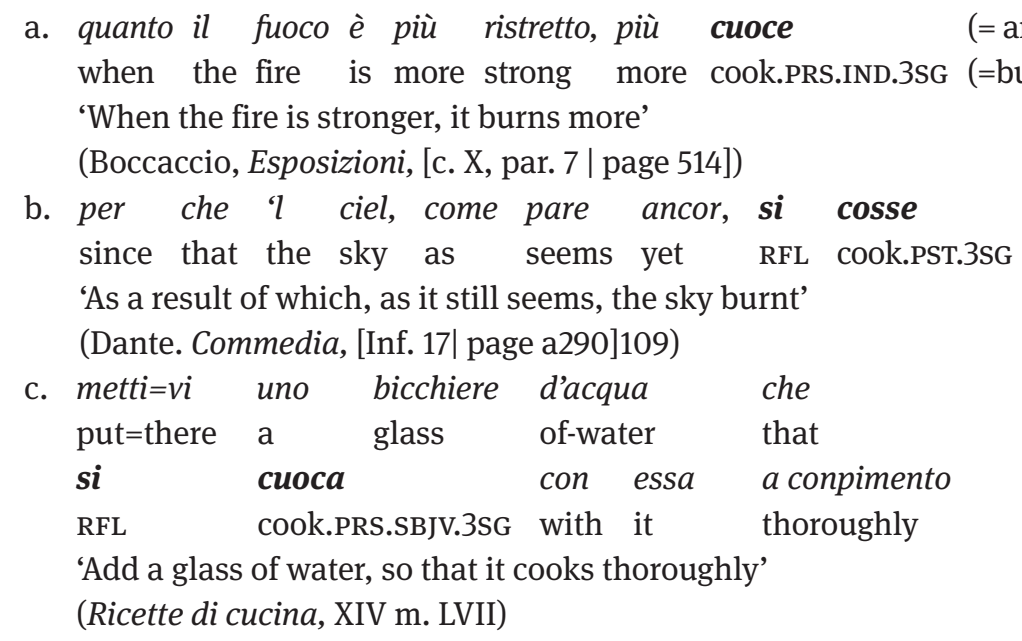

The different encoding at times also reveals the existence of regional variation: for instance, whereas in Old Florentine the achievement verb accendere 'to ignite' occurs mainly in the reflexive form (20a), in Old Pisan (20b-c) both strategies are well-attested, as shown in (20b-c):

(20) a. nel tempio de' Dei s' accese il fuoco in-the temple of-the gods RFL ignite.PST.3SG the fire 'Fire ignited in the gods' temple'

(Giamboni, Bono. Delle Storie contra i Pagani di ..., [L. 4, cap. 12 | page 230])

b. come carbon, che'n fuoco accende

like charcoal that-in fire ignite.PRS.IND.3SG

'Like charcoal that ignites'

(Fazio degli Uberti. Dittamondo, [L. 5, cap. 25 | page 409]) 
c. (ilfuoco) che $\boldsymbol{s}^{\prime}$ accese in quell'anno the fire that RFL ignite.PST.3SG in that-year 'The fire that ignited that year'

(Fazio degli Uberti. Dittamondo, [L. 1, cap. 24 | page 69])

In compound tenses the reflexive mainly occurs with telic verbs (i.e. achievements and different types of accomplishments), such as accendere 'to ignite' in (21a) and mutare 'to change' in (21b). There are also rare examples with gradual completion verbs, e.g. ampliare ‘to enlarge’ (21c) (Cennamo 2012):
a. credeano
di spontanea
volontà
thought.3P
of spontaneous
will
acceso
si fosse
(sc. il tumulto)
ignite.PP.F.SG RFL be.IMPF.SBJV.3SG (sc. the turmoil)
'They thought that [the tumult] had arisen spontaneously (lit. ignited)'
(Deca terza di Tito Livio [L 10, cap. 6, page 454])
b. se in tenebre si fosse mutato siffatto
if in darkness RFL be.IMPF.SBJV.3Sg change.PP.M.SG such
giorno!
day
'If the day had turned to night'
(Boccaccio. Fiammetta, [cap. 1, par. 8|25])
c. verso l'Occidente miserabilmente $\boldsymbol{s}$ '
towards the-West wretchedly $\mathbf{R F L}$

$\begin{array}{lll}\text { era } & \text { ampliata } & \text { (sc. pestilenza) } \\ \text { be.IMPF.IND.3SG } & \text { spread.PP.F.SG } & \text { (sc. plague) }\end{array}$
'The plague had spread towards West'
(Boccaccio. Decameron, [Introduzione / 9])

However, most typically the non-reflexive, labile form is found in compound tenses, as shown in (22a-b) for the verbs gelare 'to ice' and cuocere 'to cook' (see also Cennamo 2012: 407-410):

(22) a. del sangue... della sua madre che $\grave{\boldsymbol{e}}$ of-the blood... of-the his mother that be.PRS.IND.3sG

gelato ( ${ }^{\star}$ si è gelato)

freeze.PP.M.SG

'Of his mother's blood ... that froze'

(Libro di Sidrach, [cap. 294 | page 323]) 


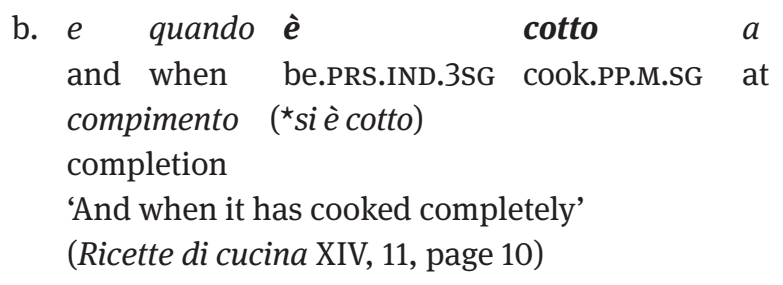

In compound tenses the occurrence of the reflexive morpheme resolves the ambiguity of the pattern BE + PP in the perfect/pluperfect, which allows for three possible readings: active (anticausative), (resultative stative) passive and adjectival (i.e. result state) with telic predicates, as in (23a), continuing the Late Latin ambiguity of the sequence BE + PP discussed in section 3.1.2 (see Brambilla Ageno 1964: 186-199; Cennamo 2003; Cennamo 2012; Cennamo, Ciconte and Andriani 2020 for other early Italo-Romance varieties):

a. Ora mi fate venire una lancia, perciò
now to.me make come a spear since
che la mia $\operatorname{è}$ rotta
that the mine be.PRS.IND.3SG break.PSTP.PTCPF.SG
'Now let me have a spear, since mine broke (anticausative)/has
broken (passive)/is broken (result state)'
(Tristano Ricc. App., page 376)
b. la cordellina del pesce di legno $\boldsymbol{s}$ ' era
the little_cord of-the fish of wood RFL be.IMPF.IND.3SG
rotta
break.PP.F.SG
'The wooden fish's string had broken.'
(Sacchetti. Trecentonovelle, 216, page 561. 24)

By contrast, when SE occurs, only the active (anticausative) interpretation of the construction is possible, as illustrated in (23b).

\subsubsection{Constraints on the distribution of the anticausative strategies in Old Italian}

The analysis of some 13th-14th century Florentine texts shows the relevance of the aspectual template of verbs and the meaning components lexicalized in the verbal root (e.g. the type of change) in determining the distribution of the anticausativization strategies. 
More specifically, in simplex tenses the reflexive, albeit occurring in apparently free variation with the active intransitive (i.e. lability), tends to be the only/ main anticausative strategy with some achievements, and is excluded with activity verbs, with which its occurrence gives the pattern a passive interpretation. Conversely, the non-reflexive, labile pattern shows a wider range of uses, since it is found also with telic/punctual predicates, e.g. with achievements and accomplishments, including also gradual completion verbs. The alternation between the reflexive and the labile strategies also involves aspectuals.

In compound tenses the pattern without the reflexive is more frequent. The rare examples with si are confined to achievements and accomplishments, i.e. verbs which lexicalize a final goal/result state.

Thus, the data reveal the tendency for the reflexive morpheme to occur with inherently telic, punctual verbs in both simplex and compound tenses, as well as the use of the labile strategy with gradual completion verbs and generally with verbs which do not lexicalize a final goal/result state in compound tenses, as schematized in Table 1.

Table 1: Anticausative strategies and their distribution in Old Florentine

\begin{tabular}{|c|c|c|c|}
\hline Strategy & Verb class & Simplex tenses & $\begin{array}{l}\text { Compound } \\
\text { tenses }\end{array}$ \\
\hline +Sı (only/mainly) & $\begin{array}{l}\text { (some) achievements (spezzare 'to } \\
\text { crack') }\end{array}$ & + & $\begin{array}{l}+ \\
\text { (rare) }\end{array}$ \\
\hline $\begin{array}{l} \pm \mathrm{SI} \text { (free } \\
\text { alternation in } \\
\text { simplex tenses) }\end{array}$ & $\begin{array}{l}\text { (some) achievements (frangere 'to } \\
\text { smash', rompere 'to break') } \\
\text { (different types of) accomplishments } \\
\text { (aprire 'to open', mutare 'to change', } \\
\text { cuocere 'to burn', allagare 'to flood') } \\
\text { gradual completion verbs (scurare 'to } \\
\text { darken', seccare 'to dry', ampliare 'to } \\
\text { enlarge', aumentare 'to increase') } \\
\text { aspectuals (beginning, termination, } \\
\text { continuation of an eventuality) } \\
\text { (cominciare 'to begin', cessare 'to stop', } \\
\text { continuare 'to continue') }\end{array}$ & $\begin{array}{l}+ \\
+\end{array}$ & $\begin{array}{c}-\mathrm{s} \mathrm{I} \\
(\text { rarely }+\mathrm{sl}) \\
-\mathrm{sI} \\
(\text { rarely }+\mathrm{sl}) \\
-\mathrm{sl}\end{array}$ \\
\hline -sı (lability) & $\begin{array}{l}\text { (some) accomplishments (cuocere 'to } \\
\text { cook') } \\
\text { (some) activities (bollire 'to boil') }\end{array}$ & + & + \\
\hline
\end{tabular}


Summing up, the analysis of early Florentine texts shows the gradual establishing of the reflexive as the main/only anticausative strategy with some aspectual classes of verbs, namely those which lexically encode a final goal/ result state, both in simplex and compound tenses, where si is gradually penetrating into the anticausative domain starting from telic verbs. Si, however, has not become a marker of telicity yet, i.e. of a final goal/result or target state, as in contemporary Italian (Cennamo and Jezek 2011; Cennamo 2012), as revealed by the free alternation between the reflexive/non reflexive forms with verbs which allow both an activity/processual reading and a result interpretation (e.g. cuocere 'to cook, burn', gelare 'to freeze', ardere 'to burn'). Interestingly, in compound tenses with these verbs the only auxiliary used with the non-reflexive strategy is BE, unlike in contemporary Italian, where both HAVE and BE occur (see section 4).

\subsection{Diachrony of anticausatives in French}

The Old French texts reveal the existence of only one anticausativization strategy at the end of the 12th century, the active intransitive, i.e. the labile pattern, as shown in (24a-d), with apparently only one example with the reflexive form attested in the early 12th century Chanson de Roland (25a) (and one in the Bestiaire) (Hatcher 1942: 126, note 72). ${ }^{9}$ In Old French (12th - 13th century) anticausativization, most typically encoded through the formally unmarked, labile pattern, occurs with change of state verbs, the core of the category: achievements (24a-f), accomplishments (24g), aspectuals denoting the beginning and termination of an eventuality such as begin and end/complete, as shown in (24h) for the verb commenser 'to begin' (examples and discussion from Heidinger 2010: 33, 94, 2014: 1013-1014):

\footnotetext{
9 The corpus employed for the analysis consists of the texts investigated by Heidinger (2010), covering all stages of the history of the language, from Old French to contemporary French, including the Chanson de Roland (Rol.) (1100), Le Voyage de Saint Brendan (Bre.) (1112), the Roman de Thèbes (Thè.) (1160), Lancelot (Lanc.) (1171) and Guillaume d'Angleterre (Gui.) (1175) as well as the Altfranzösischen Wörterbuch for Old French, the electronic text corpus Dictionnaire de Moyen Français (DMF) for Middle French (14th-15th century), the Frantext for Pre-Classical and Classical French (16th-18th century), the Trésor de la Langue Française informatisé (TFLi) for Modern French (19th century onwards) (see discussion in Heidinger 2010: 25-32, 68, note 1 and references therein).
} 
(24) a. L'espee cruist, ne fruisset ne the-sword creak.PRS.IND.3SG not burst.PRS.IND.3SG neither ne brise

not break.PRS.IND.3SG

'The sword creaks, but does not burst nor break' (Rol.; Heidinger 2010: 31) (1100)

b. Que sa lance a estros peçoie that his lance suddenly break.PRS.IND.3SG 'That his lance breaks into pieces' (Lanc., verse 859) (1171)

c. Vos plaies... escrevastes your wounds break_open.PRS.IND.3SPL 'Your wounds burst open' (Lanc., verse 4899f.) (1171)

d. La voile ront et li maz froisse the canvas break.PRS.IND.3SG and the mast crush.PRS.IND.3sG 'The canvas breaks and the mast breaks into pieces' (Gui., verse 239) (1175)

e. Tranche li fuz et ront li fers splinter.PRS.IND.3SG the wood and break_up.PRS.IND.3SG the iron 'The wood splinters and the iron breaks' (Lanc., verse 2702)

f. Tuz lur escuz ifruissent et esquassent all their shields burst.PST.3PL and shatter.PST.3PL 'Their shields burst and shattered' (Rol., verse 3879) (1100)

g. Idunc agreget le doel et la pitet then aggregate/join.PRS.IND.3SG the pain and the grief 'then pain and grief increase' (Rol., verse 2206)

h. Des or comance sa raison thus now begin.PRS.IND.3SG his story 'Thus now his story begins' (Lanc., verse 30)

The first rare examples of the reflexive strategy to mark anticausativization are attested by the 12th century, and comprise different types of change of state verbs: accomplishments (e.g. guerir 'to heal', tordre 'to bend', changer 'to change', descouvrir 'to manifest', ouvrir 'to open', monter 'to go up, rise', deviser 'to divide, inter- 
sect', lever 'to rise') (25a-d), also with variable telicity (e.g. gradual completion verbs such as refroidir 'to cool', accoitre 'to increase', décroite 'to decrease'), aspectuals (e.g. commenser 'to begin') (25e), alternating with the labile form (Heidinger 2014: 1009) (see also Table 2). Some aspectuals (e.g. parfaire 'to finish/complete', only appear with SE in an anticausative pattern, already in 12th century Old French (cf. Table 2). From the 15th century onwards (i.e. from late Middle French) and even more so in Modern French, the use of SE as a marker of anticausativization increases, spreading to a wider number of telic predicates (both achievements and accomplishments) (Heidinger 2010: 29; 73), alternating with the active intransitive, albeit an increasing number of verbs only displays SE in the anticausative pattern (Table 2).

a. se levet la puldre

RFL rise.PRS.IND.3SG the dust

'The dust rises'

(Rol., verse 3633; Hatcher 1943: 126, note 72)

b. quant li segrei de mon cour s ouvre

when the secret of my heart RFL open.PRS.IND.3SG

et mis corage se descovre

and my courage RFL manifest.PRS.IND.3sG

'When the secret of my heart opens and my courage reveals itself'

(Le livre des manieres de Etienne de Fougeres, 1776; NCA; mod. StH)

c. la vie terrienne se change sovant

the path earthly RFL change.3SG often

'The earthly life often changes'

(L'Historie de Barlaam et Josaphat, 1250; NCA; Heidinger 2010: 86)

d. Ils (sc.lescoeurs) se fondent aux rayons du soleil they the hearts REFL melt.3PL at rays of.the sun 'They (sc. the hearts) melt in the rays of the sun'

(Camus, 1615; Frantext; Heidinger 2010: 80)

e. $e$ se commensse le seruise

and RFL begin.3SG the service

'And the service begins'

(La vie du pape Saint Gregoire, 1175; NCA; Heidinger 2010: 86)

f. Car justice divine se manifeste en extermination des

because justice divine RFL manifest.3SG in estermination of.the reprouvés

reprobates

'Because divine justice manifests itself in the extermination of the reprobates' (Chartier, 1429; DMF1; Heidinger 2010: 80) 
g. ou la plume en $l$ air se souslieve where the feather in the air RFL raise.3SG 'Where the feather rises in the air' (Le Bestiaire d'amour rimé, 1250; NCA; Heidinger 2010: 80)

h. L' eue en la terre $s$ abaisse the water into the earth RFL go_down.PRS.IND.3SG 'The water sinks into the earth'

(Chronicle des ducs de Normandie par Benoit, 1175; NCA; Heidinger 2010: 30)

Already from its early (12th-13th century) attestations, anticausative SE is found in compound tenses, with the auxiliary BE, as illustrated in (26a-b) for the gradual completion verbs refreidier 'to cool (down)' and monter 'to go up, to rise'. The non-reflexive pattern, however, is the strategy most typically found, also in Middle French, as shown in (26c-d), from the 14th century (Heidinger 2010: 191):
a. quant la paie $s$ est
refreidie
when the wound RFL be.PRS.IND.3SG cool.PST.PTCP.F.SG
'When the wound cooled'
(Miracle de Notre Dame de Chartres de Jean le Marchant, 1262; NCA;
Heidinger 2010: 30)
b. $\boldsymbol{S}$ est antre eus la tançons montee
RFL be.PRS.IND.3SG among them the tensions rise.PST.PTCP.F.PL 'The tensions between them increased'
(Guillaume d'Angleterre, 1061 (1175); Heidinger 2010: 34)
c. parou il est
rompu
where it be.PRS.IND.3sG break.PST.PTCP.M.SG
'Where it broke'
(Miracles de Nostre Dame; Förster 1908: 93)
d. Més ma vie est
tournée
en desespoir
but my life be.PRS.IND.3Sg turn.PST.PTCP.F.SG into despair
'But my life turned into despair'
(Froissart I, 129, 1471; Förster 1908: 83)

With some achievement verbs such as briser 'to break', the labile pattern is the only attested form in early Old French (e.g. the Chanson de Roland), alternating with the reflexive strategy at a later stage (e.g. in Classical French), which remains the only allowed strategy in Modern and contemporary French. By contrast, accomplishments of variable telicity, gradual completion verbs such as abaisser 'to make/become less', adoucir 'to make/become softer', indefinite change verbs such as changer 'to change', and other accomplishments such as 
ouvrir 'open', denoting a target state, alternate the two strategies already in Old French. Aspectuals denoting the termination of an eventuality such as parfaire 'to complete', on the other hand, occur in the se form only, from their early attestations, as shown in Table 2. Other gradual completion verbs (e.g. augmenter 'to increase', grossir 'to grow, gain weight', empirer 'to worsen'), alternating the reflexive and labile patterns in Pre-Classical and Classical French (i.e. the 16th17th centuries) (Heidinger 2010: 157-171), subsequently show an increase in the labile form, which ousts the reflexive in contemporary French (Heidinger 2014: 1013-1018). According to Heidinger (2010, 2014), no differences are detectable among the verb classes with which the reflexive strategy is gradually introduced as a marker of the anticausative alternation, apart from the occurrence of a high number of change of state verbs.

However, the diachronic data from French also appear to show the gradual association of SE with verbs lexicalizing change, becoming fixed, i.e. obligatory with some achievements and accomplishments, i.e. highly telic verbs, already in their first attestations (cf. Old French parfaire 'to complete', Middle French remplir 'to fill', 18th century briser 'to break', etc.), subsequently also with some verbs of variable telicity, including some gradual completion verbs (e.g. accroître 'to increase', amplifier ‘to increase, intensify', vider ‘to become empty').

\subsubsection{Constraints on the distribution of anticausative strategies in the diachrony of French}

Also for the diachrony of French, therefore, the data appear to witness the gradual emergence of aspectual notions, interacting with the idiosyncratic aspects of the verb meaning, such as the type of change lexicalized in its root (e.g., target/result state, attainment/non-attainment of a final state), in determining the (optional/ obligatory) occurrence of SE. The diachronic data point to the gradual spread of SE as an anticausativization strategy, starting from the core of the category, (+ telic, \pm punctual) verbs of change. The extension of SE strongly increases after the Middle French period, especially from the 17th century onwards, and nowadays the reflexive morpheme is very widespread as an anticausative strategy, either optional or obligatory, depending on the verb, a change that is still ongoing (Heidinger 2010: 107-109 and Table 2).

Two different hypotheses have been put forward in the literature for the gradual penetration of the reflexive morpheme in a domain where lability was the only strategy available, in both simplex and compound tenses. The first hypothesis (i), concerns the ambiguity of interpretation of a pattern consisting of an inanimate argument and a verb in active morphology, between the $\mathrm{O}$ vs 
$\mathrm{S}_{0}{ }^{10}$ function of the verbal argument, owing to the relatively free word order and to the optionality of the subject (Heidinger 2010: 36). This is shown in (27a), where, out of context, the theme argument, sa lance 'his lance', could be interpreted either as the object (O) of a transitive clause 'He broke his lance into pieces', or as the subject $\left(\mathrm{S}_{0}\right)$ of an anticausative pattern 'his lance broke into pieces'. The second hypothesis (ii), involves the ambiguity of meaning of the sequence $\mathrm{BE}+$ past participle, between an eventive (anticausative) and a (dynamic/ resultative stative) passive reading of the construction, depending on the aspectual characteristics of the verb and on the context. The former type of ambiguity is viewed as accounting for the spread of SE in simplex tenses, the latter is regarded as interacting with the gradual replacement of the auxiliary BE with HAVE for unmarked anticausatives in compound tenses in Modern French (cf. 27c), that is part and parcel of a wider change involving the demise of $\mathrm{BE}$ as a perfective auxiliary with intransitive verbs (Förster 1908; Heidinger 2010: 187-193 with reference to anticausative patterns). The decrease of BE as a perfective auxiliary with non-reflexive (i.e. labile) anticausative structures (27b), would have favored the high increase of SE in compound tenses attested at this stage, with the reflexive coming to mark the eventive (i.e. anticausative) function of the construction and focus on the final goal/result state, as in (27d). This value was originally conveyed by $\mathrm{BE}$, whereby the $\mathrm{BE}+$ past participle sequence comes to have a passive reading only (dynamic/resultative passive) (Heidinger 2010: 192-193):

(27) a. sa lance peçoie

his lance break.PRS.IND.3SG

'He breaks his lance; his lance breaks'

b. il est

it be.PRS.IND.3sG break.PST.PTCP.M.SG

'It broke/it is broken/it has been broken'

c. Des pieces de bois... n' ont pas rompu

some pieces of wood not have.PRS.IND.3PL not break.PST.PTCP 'Some pieces of wood have not broken' (Littré, 18th c.; Förster 1908: 94)

$10 \mathrm{~S}, \mathrm{~A}, \mathrm{O}$ are syntactico-semantic categories, referring to the sole participant of an intransitive eventuality and to the Agent-like/Patient-like participants of a transitive eventuality, respectively (Mithun and Chafe 1999; Haspelmath 2011, among others). 


\section{d. (=26b) $\boldsymbol{S}$, est antre eus la tançons \\ RFL be.PRS.IND.3SG among them the tensions \\ montee}

rise.PST.PTCP.F.PL

'The tensions between them increased'

This hypothesis, however, does not account for the presence of reflexive anticausatives in compound tenses (with the auxiliary BE) already in Old French (albeit rarely), illustrated in (27d), $\boldsymbol{s}$ ' est antre eus la tançons montee 'the tension increased'), at a time when $\mathrm{BE}$ was the only perfective auxiliary for intransitive verbs/patterns.

By contrast, the presence of SE in compound tenses can be interpreted as disambiguating the eventive (i.e. anticausative) from the passive/resultative stative reading of the pattern $\mathrm{BE}+$ past participle and can be more clearly understood as a part of the more general phenomenon involving the reconstitution of grammatical voice in the transition from Latin to Romance (Old French in the examples illustrated above).

Summing up, the path of development emerging in the diachrony of anticausatives in French reveals that the two anticausative strategies, SE and the active intransitive, gradually come to distribute according to the aspectual properties of verbs, with SE becoming associated with verbs lexically encoding a final goal/result state already in the first occurrences of this strategy in the early Old French texts, the active intransitive being preferred for gradual completion verbs, starting from lability as the sole/main anticausative strategy. Over time, however, SE also becomes the only strategy for a number of gradual completion verbs (e.g. accroître 'to grow, increase', amplifier 'to increase, intensify', réduire 'to reduce') and other accomplishments (e.g. remplir 'to fill', transformer 'to change'), as shown in Table 2 for Modern French. This was part of the general trend of expansion of the reflexive as a marker of anticausativization to all verb classes, as witnessed by the contemporary distribution, illustrated in section 4.

Table 2: Anticausative strategies from Old to Modern French (adapted from Heidinger 2010: 94).

\begin{tabular}{|c|c|c|c|c|}
\hline Period & Strategy & Verb class & $\begin{array}{l}\text { Simplex } \\
\text { tenses }\end{array}$ & $\begin{array}{l}\text { Compound } \\
\text { tenses }\end{array}$ \\
\hline \multirow[t]{2}{*}{ Old French } & $\begin{array}{l}+\mathrm{SE}\left({ }^{*}-\mathrm{SE}\right) \\
\pm \mathrm{SE}\end{array}$ & $\begin{array}{l}\text { some aspectuals (parfaire 'to complete, } \\
\text { end') }\end{array}$ & + & \\
\hline & & achievements (tordre 'to bend') & + & \\
\hline
\end{tabular}


Table 2: (continued)

\begin{tabular}{|c|c|c|c|c|}
\hline Period & Strategy & Verb class & $\begin{array}{l}\text { Simplex } \\
\text { tenses }\end{array}$ & $\begin{array}{l}\text { Compound } \\
\text { tenses }\end{array}$ \\
\hline & & $\begin{array}{l}\text { accomplishments (changer 'to } \\
\text { change', guérir 'to heal', muer 'to } \\
\text { change', ouvrir 'to open', tourner 'to } \\
\text { turn', lever 'to rise') }\end{array}$ & + & + \\
\hline & & $\begin{array}{l}\text { gradual completion verbs (abaisser 'to } \\
\text { lower', refroidir 'to cool') }\end{array}$ & + & + \\
\hline & $-\mathrm{SE}\left({ }^{\star}+\mathrm{SE}\right)$ & achievements (briser 'to break') & + & + \\
\hline \multirow[t]{5}{*}{ Middle French } & $+\mathrm{SE}\left({ }^{\star}-\mathrm{SE}\right)$ & $\begin{array}{l}\text { accomplishments (démontrer 'to show, } \\
\text { demonstrate', manifester 'to show', } \\
\text { prouver ' to prove', remplir 'to fill') } \\
\text { aspectuals (parfaire 'to complete, end') }\end{array}$ & + & \\
\hline & $\pm \mathrm{SE}$ & achievements (briser 'to break') & + & \\
\hline & & $\begin{array}{l}\text { accomplishments (convertir 'to } \\
\text { convert, change', redoubler 'to } \\
\text { double', ouvrir 'to open') } \\
\text { aspectuals (terminer 'to end') }\end{array}$ & + & \\
\hline & & $\begin{array}{l}\text { gradual completion verbs (accoître } \\
\text { 'to increase', amollir 'to soften', } \\
\text { décroîte 'to decrease', renforcer ' to } \\
\text { strengthen') }\end{array}$ & + & + \\
\hline & $-\mathrm{SE}\left({ }^{\star}+\mathrm{SE}\right)$ & & - & - \\
\hline \multirow[t]{6}{*}{$1610-1615$} & + se $\left({ }^{\star}-\right.$ se $)$ & $\begin{array}{l}\text { accomplishments (agiter 'to shake', } \\
\text { dessécher 'to dry out', transformer 'to } \\
\text { change', perfectionner 'to complete', } \\
\text { éteindre 'to turn off, estinguish') } \\
\text { aspectuals (parfaire 'to complete, end) }\end{array}$ & + & \\
\hline & & $\begin{array}{l}\text { gradual completion verbs (putréfier } \\
\text { 'to rot', vider 'to empty', fortifier 'to } \\
\text { strengthen') }\end{array}$ & + & \\
\hline & $\pm \mathrm{SE}(=$ free & achievements (éclater 'to burst') & + & \\
\hline & $\begin{array}{l}\text { alternation } \\
\text { in simplex }\end{array}$ & $\begin{array}{l}\text { accomplishments (ouvrir 'to open', } \\
\text { changer 'to change', brûler 'to burn') }\end{array}$ & + & + \\
\hline & tenses) & $\begin{array}{l}\text { gradual completion verbs } \\
\text { (augmenter 'to increase', enlaidir 'to } \\
\text { make ugly', fondre 'to melt') }\end{array}$ & + & + \\
\hline & & & - & - \\
\hline
\end{tabular}


Table 2: (continued)

\begin{tabular}{|c|c|c|c|c|}
\hline Period & Strategy & Verb class & $\begin{array}{l}\text { Simplex } \\
\text { tenses }\end{array}$ & $\begin{array}{l}\text { Compound } \\
\text { tenses }\end{array}$ \\
\hline \multirow[t]{6}{*}{1745} & $+\mathrm{SE}\left({ }^{\star}-\mathrm{SE}\right)$ & $\begin{array}{l}\text { achievements (blesser 'to hurt') } \\
\text { accomplishments (effacer 'to erase', } \\
\text { enflammer 'to inflame', irriter 'to } \\
\text { irritate', convertir 'to convert, change } \\
\text { into') }\end{array}$ & + & \\
\hline & & $\begin{array}{l}\text { aspectuals (terminer 'to end') } \\
\text { gradual completion verbs (accroître } \\
\text { 'to increase', affaiblir 'to weaken', } \\
\text { dessécher 'to dry out', fortifier 'to } \\
\text { strengthen') }\end{array}$ & + & + \\
\hline & $\pm \mathrm{SE}$ & $\begin{array}{l}\text { achievements (romper, briser 'to } \\
\text { break') (rare) }\end{array}$ & + & \\
\hline & & $\begin{array}{l}\text { accomplishments (fermer 'to close', } \\
\text { ouvrir 'to open', multiplier 'to } \\
\text { multiply', changer 'to change') }\end{array}$ & + & \\
\hline & & $\begin{array}{l}\text { gradual completion verbs (augmenter } \\
\text { 'to increase', embellir 'to embellish', } \\
\text { enfler 'to swell', fondre 'to melt') }\end{array}$ & + & \\
\hline & $-\mathrm{SE}\left({ }^{*}+\mathrm{SE}\right)$ & & - & - \\
\hline \multirow[t]{5}{*}{1990} & $+\mathrm{SE}\left({ }^{*}-\mathrm{SE}\right)$ & $\begin{array}{l}\text { achievements (briser 'to break') } \\
\text { accomplishments (éteindre 'to turn } \\
\text { off, estinguish', remplir 'to fill', } \\
\text { transformer 'to change') }\end{array}$ & + & + \\
\hline & & $\begin{array}{l}\text { gradual completion verbs } \\
\text { (accroître 'to increase', amplifier } \\
\text { 'to increase, intensify', aplatir 'to } \\
\text { flatten', arrondir 'to round', réduire 'to } \\
\text { decrease', vider 'to empty') }\end{array}$ & + & + \\
\hline & & $\begin{array}{l}\text { achievements (plier 'to bend', romper, } \\
\text { casser 'to break') }\end{array}$ & + & + \\
\hline & $\pm \mathrm{SE}$ & $\begin{array}{l}\text { accomplishments (fermer 'to close', } \\
\text { muer 'to change', ouvrir 'to open', } \\
\text { arrêter 'to stop') }\end{array}$ & + & + \\
\hline & & $\begin{array}{l}\text { gradual completion verbs } \\
\text { (allonger 'to lengthen', multiplier 'to } \\
\text { multiply') }\end{array}$ & + & + \\
\hline Contemporary & $-\mathrm{SE}\left({ }^{*}+\mathrm{SE}\right)$ & achievements (crever 'to burst') & + & + \\
\hline French & & $\begin{array}{l}\text { gradual completion verbs } \\
\text { (augmenter 'to increase', grossir 'to } \\
\text { grow/gain weight', empirer 'to worsen') }\end{array}$ & + & + \\
\hline
\end{tabular}




\section{Anticausatives in contemporary Italian and French}

In contemporary Italian and French, three subclasses are usually identified in the literature, on the basis of the presence, absence, optionality of the reflexive and of auxiliary selection (HAVE, BE or both). As illustrated in (28)-(30), the three subclasses are not aspectually homogenous, neither in Italian or French.

Class 1, characterized by verbs always taking SE in the anticausative construction, with selection of the auxiliary $\mathrm{BE}$, comprises achievements (Fr. se briser 'to break'; It. spezzarsi 'to crack'), different types of accomplishments (Fr. se calcifier 'to become chalky', s'agrandir 'to get larger'; It. chiudersi 'to close', gonfiarsi 'to swell'), as well as activities (Fr. s'exprimer/It. esprimersi 'to express') and states (Fr. se fonder/It. fondarsi 'to be based') (Labelle 1992; Legendre and Smolensky 2009: 231; Martin and Schäfer 2014 on French; Folli 2002; Bentley 2006; Cennamo and Jezek 2011; Cennamo 2012 for Italian; Manente 2008; Schäfer 2008, among others), as shown in (28) (French examples from Legendre and Smolensky 2009: 231):

Class $1[+\mathrm{SE}](\mathrm{aux} \mathrm{BE})$

Achievements: Fr. se briser 'to break'; It. spezzarsi 'to crack', rompersi 'to break', spegnersi 'to turn out'.

Accomplishments: Fr. s'ameliorer 'to get better', se calcifier 'to become chalky', se déteériorer 'to get worse', se gâter 'to go bad', s'alléger 'to get lighter', s'assécher 'to dry out', s'agrandir 'to get larger', s'amaigrir 'to get thinner', s'alourdir 'to get heavier'; It. svuotarsi 'to empty', gonfiarsi 'to swell', aprirsi 'to open', chiudersi 'to close', dividersi 'to divide'.

Activities: Fr. s'exprimer/It. esprimersi 'to express'.

States: Fr. se fonder, se baser/It. fondarsi, basarsi 'to be based'.

Class 2 [-SE] (selecting the auxiliary BE in Italian, HAVE in French in compound tenses), includes mostly accomplishments with variable telicity, such as gradual completion verbs (Fr. durcir 'to harden', sécher 'to dry'; It. aumentare 'to increase', migliorare 'to improve'), as well as some achievements (e.g. crever 'to burst', claquer 'to slam') and accomplishments lexicalizing a final point, such as French moisir 'to grow moldy', fletrir 'to wither' and Italian affondare 'to sink', guarire 'to heal': 
(29) Class 2 [-SE] (aux HAVE (Fr.); aux BE (It.))

Achievements: Fr. crever 'to burst', claquer 'to slam'.

Accomplishments: Fr. moisir 'to grow moldly', fletrir 'to wither', durcir 'to harden', sécher 'to dry'; It. aumentare 'to increase', diminuire 'to decrease', migliorare 'to improve', cambiare 'to change', affondare 'to sink', guarire 'to heal'.

Activities: Fr. bouiller/It. bollire 'to boil'.

Class 3 ([ $\pm \mathrm{SE}]$ ), exemplified in (30), comprises different types of accomplishments, including also gradual completion verbs such as (se) ramollir 'to soften', (s')augmenter 'to increase', as well as achievements in French (e.g. (se) rompre 'to break up'). In Italian verbs with optional SE in the anticausative pattern are accomplishments consisting of a change process and an optional telos (e.g. cuocer(si) 'to cook', bruciar(si) 'to burn') (Folli 2002; Cennamo and Jezek 2011, Cennamo 2012: 401-403, among others). In both languages the non-reflexive pattern focuses on the transition itself, on the process, whilst in the reflexive form the focus is on the endpoint of the process, the attainment of a result state (see Labelle 1992; Manente 2008; Legendre and Smolensky 2009; Heidinger 2010, 2015, 2019 and references therein for French; Martin and Schäfer 2014; Heidinger 2019 for a different interpretation of the optionality of the reflexive). In French in compound tenses the auxiliary selected is always HAVE in the non-reflexive pattern; in Italian in the [SE] pattern both HAVE and BE may occur, conveying an aspectual difference. The construction with $\mathrm{BE}$ tends to have a telic interpretation, signalling either a result state (31a) or an event (31b), whereas the structure with HAVE tends to trigger an atelic reading (31c). However, with some verbs (e.g. bruciare 'to burn', stingere 'to fade') BE is acceptable also in an atelic context and HAVE may occur in a telic one, as shown in (31d) (Cennamo 2012: 402; Cennamo and Jezek 2011: 817-818):

(30) Class 3 [ \pm SE] (+SE: aux BE; -SE: HAVE/BE (It); HAVE (Fr.)

Achievements: (se) casser 'to break', (se) rompre 'to break up'.

Accomplishments: Fr. (se) cristalliser 'to crystallize', (se) gonfier 'to swell up', (se) tarir 'to dry up', (se) rétrécir 'to shrink', (se) noircir 'to blacken', (se) refroidit 'to cool down', (se) ramollir 'to soften', (se) couler 'to sink', (s')augmenter 'to increase', (s')enfler 'to swell'; It. seccar(si) 'to dry (out)', bruciar(si) 'to burn', cuocer(si) 'to cook', gelar(si) 'to ice', fonder(si) 'to melt'. 


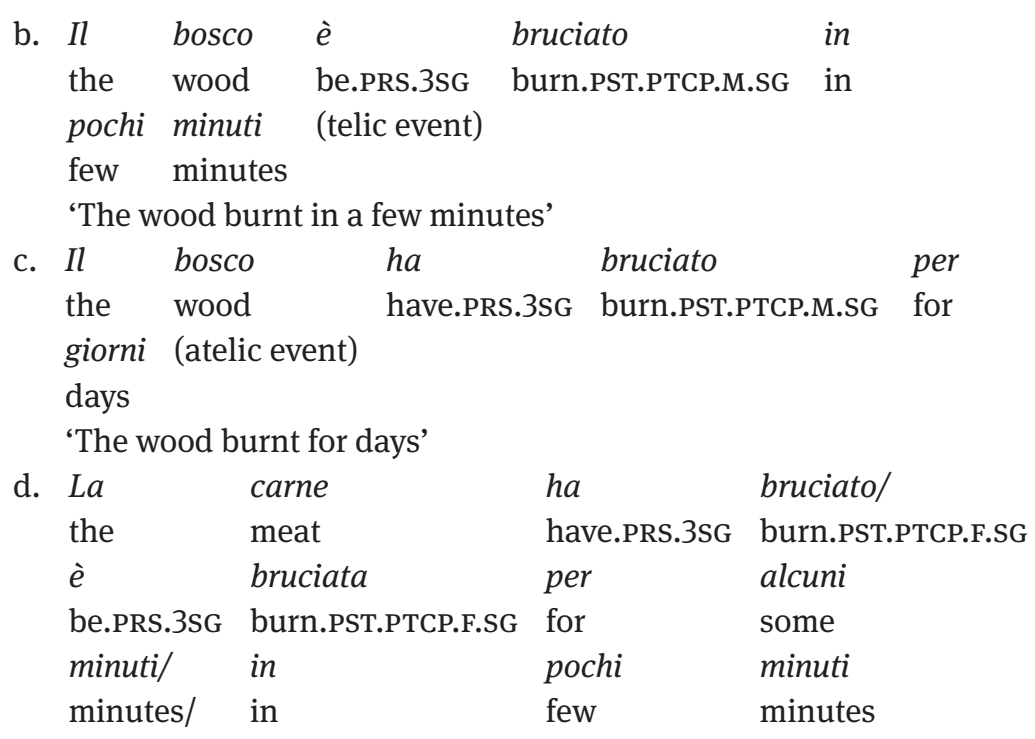

'The meat burnt for some minutes/in a few minutes'

\section{Aspectually relevant lexical properties of verbs and the distribution of anticausative strategies}

The data investigated fall within a more general diachronic tendency, clearly attested in Late Latin for its final stage, whereby anticausative sE spreads to all verbs classes, regardless of their aspectual characteristics, a change that is also clearly perceivable in the diachrony of French and still ongoing in the language (Heidinger 2010: 107), interacting with the voice domain in the languages analysed. The synchronic and diachronic distribution of the anticausativization strategies discussed can be insightfully accounted for by means of a scale-based classification of the temporal structure of verbs (Beavers 2008; Rappaport Hovav 2008), which takes into account the role played by the properties encoded in the lexical meaning of the verb, the root, in determining the aspectual schemas and morphosyntactic realization of predicates (Levin and Rappaport Hovav 2005; Rappaport Hovav 2008, and recent discussion of the internal structure of roots and their including both templatic and idiosyncratic aspects in Beavers and Koontz-Garboden 2020). This model allows us to describe the aspectual variability and the different morphosyntactic behavior of verbs entering the anticausative alternation in the languages investigated, both synchronically and diachronically (sections 5.1- 5.2). 


\subsection{A scale-based classification of verbs}

Following a recent proposal concerning the classification of verbs on the basis of their aspectually relevant lexical properties (Beavers 2008; Rappaport Hovav 2008), dynamic verbs which can be viewed as involving the notion of change (Dowty 1979; Rappaport Hovav 2008: 16) can be classified accordingly, in relation to the type of change, as scalar/non-scalar change verbs. The change lexicalized by change of state verbs (i.e. a property scale) is scalar, involving a set of ordered values for a particular attribute, as with English widen and open. By contrast, the change lexicalized by activities such as jog, run, waltz is nonscalar (i.e. it involves a complex, unordered change and it is not associated with a scale) (Rappaport Hovav 2008: 17-20). Verbs that lexically specify a scalar change, may be further distinguished, in relation to the nature of the scale, as associated with a binary, two-point scale, or a polar, multi-point scale (Beavers 2008; see also binary and polar opposition in Pustejovsky 2001).

In light of these assumptions, Rappaport Hovav (2008: 38-39) puts forward the classification in (32):

(32) Nonscalar changes: activities (play, jog) [+change]

Scalar change verbs:

- Two-point scalar change verbs (presence/absence of a property): achievements (e.g. die, break, crack)

- Multi-point scalar change verbs (existence of many values for the particular attribute lexicalized in the scale): different types of accomplishments (e.g. widen, increase, open, swell)

States: [-change] (e.g., resemble, have, know)

The different morphosyntactic behavior of a verb may reflect the different meaning component(s) which it lexicalizes (Levin and Rappaport Hovav 2005; Rappaport Hovav 2008). States encode no change; achievements encode a two-point scalar change, accomplishments encode a multi-point scalar change. The lexical encoding of a scalar change is responsible for the varying aspectual interpretation of gradual completion verb, their 'hybrid' nature (i.e. their showing properties of activities, achievements and accomplishments) (Rappaport Hovav 2008: 22-28, 2014: 263-266, 274-281). 


\subsection{Relevance of a scale-based verb classification for Latin, Italian and French anticausatives}

The notion of scalar change, in particular the distinction between a two-point and a multi-point scalar change, together with the idea that the different morphosyntactic behavior of a verb may reflect the different meaning components lexicalized in its various uses, seems to offer an interesting generalization for capturing the occurrence of the reflexive morpheme SE with anticausatives in Latin, Italian and French, both diachronically and synchronically.

More specifically, the reflexive morpheme SE in some of its anticausative uses may be regarded as a marker of the presence of a final goal/result/target state in the lexical meaning of a verb, occurring with verbs lexically encoding a scalar change, either in all their uses or in some of them. Achievements (i.e. two-point scalar change verbs), such as Classical Latin rumpere se/Italian rompersi/French se briser, 'to break', and de-adjectival verbs whose root denotes the maximal/ minimal value of a closed/open scale, such as Italian (s)vuotarsi /French se vider 'to empty' and Italian gonfiarsi 'to swell, inflate', always entail the presence of a final goal/result/target state and appear with the reflexive marker in the anticausative pattern. Accomplishment verbs denoting a change process with an optional telos, such as Italian bruciar(si) 'to burn', cuocer(si) 'to cook', gelar(si) 'to freeze', fonder(si) 'to melt', French (se) ramollir 'to soften', (se) refroidir 'to cool down', entail the presence of a final goal/result/target state only in some of their uses, this being signalled by the presence of SE. These verbs appear instead in the intransitive form without SE under their processual/transitional reading, i.e. when they do not lexicalize a final goal/result/target state (see also Sorace 2000: 872).

The lack of SE with verbs which lexicalize a final state such as Italian affondare 'to sink', guarire 'to heal', cambiare 'to change'11 and with achievements such as French crever 'to burst', and punctual activities (i.e. semelfactives) such as claquer 'to slam', can be accounted for if the synchronic distribution is viewed as a part of a long-term diachronic change, involving the extension of the reflexive to all verb classes, a change that is aspectually streamlined, and takes place at different 'paces' in the languages analysed. In Latin, SE initially occurs only with two-point scalar change verbs (i.e. achievements) and multipoint scalar change

11 These verbs, however, always take SE in southern regional varieties of Italian and dialects, e.g. Neapolitan/Molisan il tempo s'è cambiato the weather RFL-be.PRs.3SG change.PST.PTCP.M.SG 'the weather changed', thereby confirming the generalization put forward, concerning the presence of the reflexive marker in the anticausative pattern with verbs lexically encoding a scalar change (cf. also Cennamo and Jezek 2011: 814; Cennamo 2012: 400-401). 
verbs lexically encoding a result/target state). Only at subsequent stages is SE found with multi-point scalar change verbs of variable telicity such as gradual completion verbs, and with non-scalar change verbs (i.e. activities). In French the reflexive penetrates into the original labile system from scalar change verbs (two-point and multi-point), i.e. some achievements and accomplishments, gradually spreading to other verbs with the same aspectual characteristics, becoming obligatory initially with two-point scalar change verbs, i.e. achievements and multipoint-scalar change verbs lexicalizing a result state (e.g. accomplishments such as remplir 'to fill'), gradually extending to nonscalar change verbs (e.g. activities such as exprimer 'to express') and even states (e.g. baser 'to base'). Italian shows a similar path of development, though taking off from a different starting point, the alternation between the reflexive and labile strategy with all aspectual classes allowing anticausativization (except activities). A deeper investigation of the factors determining the behavior of verbs which escape the generalization proposed needs to be carried out, however, in order to confirm the diachronic tendencies described and the hypothesis put forward.

\section{Conclusions}

Two paths of change emerge in the diachrony of anticausatives in the Romance languages investigated and their Latin antecedents:

- the gradual association of SE with verbs lexicalizing telic change in Italian and French, starting from the alternation between the reflexive and the active intransitive in Old Italian, and lability as the sole/main anticausative strategy in Old French, with aspectual notions such as telicity gaining ground in determining the obligatory occurrence/preference for SE over the active intransitive in Old Florentine and Old/Middle French;

- the demise of the interplay of thematic and aspectual notions in the encoding of anticausatives in Latin, leading to the equivalence and ensuing alternation among the anticausativization strategies, with SE no longer occurring only with telic and/or punctual verbs.

More specifically, the reflexive morpheme sE can be interpreted as a marker of Actor suppression at argument structure, and of the presence of a final goal/ result/target state in the lexical meaning of a verb, occurring with verbs lexically encoding a scalar change, either in all their uses, or in some of them. Thus, the data investigated appear to offer an interesting contribution to the current debate 
on the role played by the idiosyncratic and templatic aspects of verb meaning, and their interaction and integration in determining argument realization. In point of fact, they show the relevance of these notions also for the diachrony of anticausativization, a syntactic domain which lies at the heart of the issue of the non-homogeneous internal temporal properties of accomplishments and of how particular components of lexicalized meaning may determine the aspectual properties of predicates and argument realization.

\section{References}

Adams, James N. 2013. Social variation and the Latin language. Cambridge: Cambridge University Press.

Alexiadou, Artemis. 2010. On the morpho-syntax of anticausative verbs. In Malka Rappaport Hovav, Edith Doron \& Ivy Sichel (eds.), Syntax, lexical semantics and event structure, 177-203. Oxford: Oxford University Press.

Alexiadou, Artemis. 2014. The problem with internally caused change-of-state verbs. Linguistics 52. 879-910.

Alexiadou, Artemis, Elena Anagnostopoulou \& Florian Schäfer. 2015. External arguments in transitivity alternations: A layering approach. Oxford: Oxford University Press.

Beavers, John. 2008. Scalar complexity and the structure of events. In Johannes Dölling, Tatjana Heyde-Zybatow \& Martin Schäfer (eds.), Event structures in linguistic form and interpretation, 245-265. Berlin \& New York: Mouton de Gruyter.

Beavers, John \& Andrew Koontz-Garboden. 2012. Manner and result in the roots of verbal meaning. Linguistic Inquiry 43 (3). 331-369.

Beavers, John \& Andrew Koontz-Garboden. 2020. The roots of verbal meaning. Oxford: Oxford University Press.

Bentley, Delia. 2006. Split intransitivity in Italian. Berlin \& New York: Mouton de Gruyter.

Bertinetto, Pier Marco \& Mario Squartini 1995. An attempt at defining the class of 'gradual completion verbs'. In Pier Marco Bertinetto, Valentina Bianchi, James Higginbotham \& Mario Squartini (eds.), Temporal reference, aspect and actionality. Vol. 1: Semantic and syntactic perspectives, 11-26. Torino: Rosenberg \& Sellier.

Brambilla Ageno, Franca. 1964. Il verbo nell'italiano antico. Milano \& Napoli: Ricciardi.

Cennamo, Michela. 1995. Transitivity and VS order in Italian reflexives. Sprachtypologie und Universalienforschung 48 (1/2). 84-105.

Cennamo, Michela. 1998. The loss of the voice dimension between Late Latin and early Romance. In Monika Schmid, Jennifer R. Austin \& Dieter Stein (eds.), Historical Linguistics 1997, 81-100. Amsterdam \& Philadelphia: John Benjamins.

Cennamo, Michela. 2001. Classi verbali e cambiamento sintattico: La reinterpretazione passiva del costrutto riflessivo. In Zsuzanna Fàbiàn \& Giampaolo Salvi (eds.), Semantica e lessicologia storiche. Atti del XXXII Congresso Internazionale della Società di Linguistica Italiana, 225-242. Roma: Bulzoni. 
Cennamo, Michela. 2003. Perifrasi passive in testi non toscani delle origini. In Nicoletta Maraschio \& Teresa Poggi Salani (eds.), Italia linguistica anno Mille. Italia linguistica anno Duemila, 105-127. Roma: Bulzoni.

Cennamo, Michela. 2005. Passive auxiliaries in Late Latin. In Sándor Kiss, Luca Mondin \& Giampaolo Salvi (eds), Latin et langues romanes. Études de linguistique offertes à József Herman à l'occasion de son 80ème anniversaire, 177-194. Tübingen: Niemeyer.

Cennamo, Michela. 2006. The rise and grammaticalization paths of Latin fieri and facere as passive auxiliaries. In Werner Abraham \& Larisa Leisö (eds.), Passivization and typology, 311-336. Amsterdam \& Philadelphia: John Benjamins.

Cennamo, Michela. 2009. Argument structure and alignment variations and changes in Late Latin. In Johanna Barðdal \& Shobana L. Chelliah (eds.), The role of semantic, pragmatic and discourse factors in the development of case, 307-346. Amsterdam \& Philadelphia: John Benjamins.

Cennamo, Michela. 2012. Aspectual constraints on the (anti)causative alternation in Old Italian. In Johanna Barðdal, Michela Cennamo \& Elly van Gelderen (eds.), Argument realization and change. Transactions of the Philological Society 110 (3). 394-421. Special issue.

Cennamo, Michela. 2016. Voice. In Adam Ledgeway \& Martin Maiden (eds.), The Oxford guide to the Romance languages, 967-980. Oxford: Oxford University Press.

Cennamo, Michela, Francesco Ciconte \& Luigi Andriani. 2020. The syntax and semantics of anticausatives in Early Italo-Romance. L'Italia Dialettale 81: 1-28

Cennamo, Michela, Thórhallur Eythórsson \& Johanna Barðdal. 2015. Semantic and (morpho) syntactic constraints on anticausativization: evidence from Latin and Old Norse-Icelandic. Linguistics 53.4: 677-729.

Cennamo, Michela \& Elisabetta Jezek. 2011. The anticausative alternation in Italian. In Giovanna Massariello \& Serena Dal Masi (eds.), Le interfacce, 809-823. Roma: Bulzoni.

Dowty, David R. 1979. Word meaning and Montague Grammar. Dordrecht: Reidel.

Feltenius, Leif. 1977. Intransitivizations in Latin. Uppsala: Almkvist \& Wiksell.

Flobert, Pierre. 1975. Les verbes déponents Latins des origines à Charlemagne. Paris: Les Belles Lettres.

Gianollo, Chiara. 2014. Labile verbs in Late Latin. In Leonid Kulikov \& Nikolaos Lavidas (eds.), Typology of labile verbs: Focus on diachrony. Linguistics 52 (4). 945-1002. Special Issue.

Haspelmath, Martin. 1987. Transitivity alternations of the anticausative type. In Arbeitspapier $n$ r. 5, Institut für Sprachwissenschaft, Universität zu Köln, 1-51.

Haspelmath, Martin. 1993. More on the typology of inchoative/causative verb alternations. In Bernard Comrie and Maria Polinsky (eds.), Causatives and transitivity, 87-120. Amsterdam \& Philadelphia: John Benjamins.

Haspelmath, Martin. 2011. On S, A, P, T and R as comparative concepts for alignment typology. Linguistic Typology 15. 535-567.

Haspelmath, Martin. 2016. Universals of causative and anticausative verb formation and the spontaneity scale. Lingua Posnaniensis LVIII (2). 33-63.

Hay, Jen, Christopher Kennedy \& Beth Levin. 1999. Scalar structure underlies telicity in degree achievements. In Proceedings of SALT IX, 127-144.

Heidinger, Steffen. 2010. French anticausatives. A diachronic perspective. Berlin \& New York: Mouton de Gruyter. 
Heidinger, Steffen. 2014. The persistence of labile verbs in the French causative-anticausative alternation. In Leonid Kulikov \& Nikolaos Lavidas (eds.), Typology of labile verbs: focus on diachrony. Linguistics 52 (4): 945-1002. Special Issue.

Heidinger, Steffen 2015. Causalness and the encoding of the causative-anticausative alternation in French and Spanish. Journal of Linguistics 51 (3). 562-594.

Heidinger, Steffen. 2019. Reflexive and unmarked anticausatives in French and Spanish: Frequency of transitive use and undergoer overlap. Langages 216. 53-69.

Koontz-Garboden, Andrew. 2009. Anticausativization. Natural Language and Linguistic Theory 27. 77-138.

Kuryłowicz, Jerzy. 1964. The inflectional categories of Indo-European. Heidelberg: Carl Winter. Labelle, Marie. 1992. Change of state and valency. Journal of Linguistics 28. 375-164. Lazzeroni, Romano. 2009. Causativi e transitivi indoeuropei: Fra comparazione e tipologia. Studi e Saggi Linguistici 47. 7-23.

Legendre, Geraldine \& Paul Smolensky. 2009. French inchoatives and the Unaccusative Hypothesis. In Donna Gerdts \& Maria Polinsky (eds.), Hypothesis A/Hypothesis B, 229-246. Cambridge: MIT Press.

Lepschy, Anna Laura \& Giulio Lepschy. 2006. Italian. In Keith Brown (ed.), Encyclopedia of language and linguistics, 2nd edn. Vol 6, 545-549. Oxford: Elsevier.

Levin, Beth \& Malka Rappaport Hovav. 1995. Unaccusativity. Cambridge: MIT Press.

Levin, Beth \& Malka Rappaport Hovav. 2005. Argument realization. Cambridge: Cambridge University Press.

Levin, Beth. 2017. The elasticity of verb meaning revisited. Proceedings of SALT 27. 571-599.

Maiden, Maiden. 1995. A linguistic history of Italian. London: Longman.

Manente, Mara. 2008. L'aspect, les auxilaires 'être' et 'avoir' et l'hypothèse inaccusative dans une perspective comparative Français/Italien. Venice: University of Venice PhD thesis.

Martin, Fabienne \& Florian Schäfer. 2014. Anticausatives compete but do not differ in meaning: A French case study. In Actes du Congrès Mondial de Linguistique Française 2014, 2485-2500. Berlin: FU.

Mithun, Marianne \& Wallace Chafe. 1999. What are S, A and O?. Studies in Language 23. 569-596.

Norberg, Dag. 1943. Syntaktische Forschungen auf dem Gebiete des Spätlateins und des frühen Mittellateins. Uppsala: Almkvist \& Wiksell.

Parsons, Terence. 1990. Events in the semantics of English. Cambridge, MA: MIT Press.

Pirson, Jules. 1906. Mulomedicina Chironis: La syntaxe du verbe. In Festschrift zum Allgemeinen Deutchen Neuphilologentage, 390-431. Erlangen.

Pustejovsky, James. 2001. Type construction and the logic of concepts. In Pierre Bouillon \& Federica Busa (eds.), The syntax of word meaning. Cambridge: Cambridge University Press.

Rappaport Hovav, Malka. 2008. Lexicalized meaning and the internal temporal structure of events. In Susan Rothstein (ed.), Crosslinguistic and Theoretical Approaches to the Semantics of Aspect, 13-42. Amsterdam \& Philadelphia: John Benjamins.

Rappaport Hovav, Malka. 2014. Building scalar changes. In Artemis Alexiadou, Hagit Borer \& Florian Schäfer (eds.), The syntax of roots and the roots of syntax, 261-281. Oxford: Oxford University Press.

Rappaport Hovav, Malka \& Beth Levin. 2010. Reflections on Manner/Result complementarity. In Edith Doron, Malka Rappaport Hovav \& Ivy Sichel (eds), Syntax, lexical semantics and event structure, 21-38. Oxford: Oxford University Press.

Ronconi, Alessandro. 1968. Il verbo latino. Problemi di sintassi storica. Firenze: Le Monnier. 
Schäfer, Florian. 2008. The syntax of (Anti-)Causatives. External arguments in change-of-state contexts. Amsterdam \& Philadelphia: John Benjamins.

Schäfer, Florian. 2009. The causative alternation. Language and Linguistics Compass 3 (2). 641-681.

Sorace, Antonella. 2000. Gradients in auxiliary selection with intransitive verbs, Language 76. 859-890.

Svennung, Josef. 1935. Untersuchungen zu Palladius and zur lateinischen Fach und Folkssprache. Uppsala: Almkvist \& Wiksell.

Van Valin, Robert D. Jr. 2005. Exploring the syntax-semantics interface. Cambridge: Cambridge University Press.

Van Valin, Robert D. Jr. \& Randy La Polla. 1997. Syntax: structure, meaning and function. Cambridge: Cambridge University Press.

Vendler, Zeno. 1967. Linguistics in phylosophy. Ithaca, NY: Cornell University Press.

Vincent, Nigel, Mair Parry \& Robert Hastings. 2004. Il progetto SAVI: presentazione, procedure e problemi. In Maurizio Dardano \& Luca Frenguelli (eds.), La sintassi dell'italiano antico: Atti del Convegno Internazionale di Studi, Roma TRE, 18-21 September 2002, 501-528. Roma: Aracne.

Wistrand, Eric. 1942. Über das Passivum. Gothenburg: Wettergren.

\section{Textual sources}

\section{Latin}

PHI-5 CD-ROM (The Packard Humanities Institute's Collection of Digital Latin Texts).

Cat. Agr. = Mazzarino, Antonio. 1982. (ed.), M. Porci Catonis de Agri Cultura. Leipzig: Teubner.

Cic. Div.; Rep. = Müller, Carl Friedrich W. 1890. (ed.), M. Tulli Ciceronis Scripta quae manserunt omnia. Part 4, Vol. 2. Leipzig: Teubner.

Cic. Sen. = Simbeck, Karl. 1917. (ed.), M. Tulli Ciceronis Scripta Quae Manserunt Omnia. Fasc. 47. Leipzig: Teubner.

Fredeg. Chron. $=$ Krusch, Bruno. 1888. (ed.), Fredegarii et aliorum Chronica. Vitae sanctorum. MGH Scriptores rerum Merovingicarum 2. Hanover.

Gell. NA = Marshall, Peter K. 1968. (ed.), A. Gelli Noctes Atticae. Vols. 1-2. Oxford: Clarendon Press.

Lucr. $R N=$ Martin, Joseph. 1969. (ed.), De Rerum Natura Libri Sex. Leipzig: Teubner.

Mul. Chir. = Oder, Eugenius. 1901. (ed.), Claudii Mermerii Mulomedicina Chironis. Leipzig: Teubner.

Orib. $=$ Mørland, Henning. 1940. (ed.), Oribasius Latinus. Synopsis, I-II. Oslo: Brøgger.

Ovid. Met. = Miller, Frank J. \& George P. Goold. 1977-1984. (eds.), Ovid: Metamorphoses in Two Volumes. Cambridge MA \& London: Harvard University Press \& William Heinemann.

Pall. = J.C. Schmitt. 1898. (ed.), Palladius Rutilius Taurus Aemilianus. Opus Agriculturae.

Leipzig: Teubner.

Plaut. Bacch. = Leo, Friedrich. 1895. (ed.), Plauti Comoediae. Vol. 1. Berlin: Weidmann. Plaut. Mil.; Persa = Leo, Friedrich. 1896. (ed.), Plauti Comoediae. Vol. 2. Berlin: Weidmann. 
Plin. Nat. = Mayhoff, Karl. 1892-1909. (ed.), C. Plini Secundi Naturalis Historiae libri XXXVII. Vols. 1-5. Leipzig: Teubner.

Sall. lug. = Kurfess, Alfons. 1951-1957. (ed.), C. Sallusti Crispi Catilina. Iugurtha. Fragmenta Ampliora. Leipzig: Teubner.

Varr. Men. = Astbury, Raymond. 1985. (ed.), M. Terentii Varronis Saturarum Menippearum Fragmenta. Leipzig: Teubner.

\section{Old Florentine}

Boccaccio, Decameron = Branca, Vittore, (ed.), 1976. Decameron, Florence: Accademia della Crusca.

Boccaccio, Esposizioni = Padoan, Giorgio, (ed.), 1965. Boccaccio, Giovanni. Esposizio sopra la Comedia di Dante, in Id., Tutte le opere di Giovanni Boccaccio. Vol. VI. Milan: Mondadori. Boccaccio, Fiammetta = Ageno, Franca, (ed.), 1954. Boccaccio, Giovanni. L'Elegia di Madonna Fiammetta. Paris: Tallone.

Bono Giamboni, Orosio = Tassi, Francesco, (ed.), 1849. Giamboni, Bono. Delle Storie contra $i$ Pagani di Paolo Orosio libri VII. Florence: Baracchi.

Chiose falso Boccaccio, Inf. = Vernon, William Warren, (ed.), 1846. Chiose Dette del Falso Boccaccio (Inferno). Florence: Piatti.

Dante, Commedia = Petrocchi, Giorgio, (ed.), 1966-67. Dante Alighieri, La Commedia secondo l'antica vulgata, vol. II Inferno, vol. III Purgatorio, vol. IV Paradiso. Milan: Mondadori.

Deca terza di Tito Livio = Gli ultimi sei libri della terza Deca di Tito Livio volgarizzata, in Pizzorno, Francesco, (ed.), 1845. Le Deche di T. Livio. Vol. IV. Savona: Sambolino.

Fazio degli Uberti, Dittamondo = CoRsI, GIUSEPPE, (ed.), 1952. Fazio degli Uberti. /l Dittamondo e le Rime. Bari: Laterza.

Libro di Sidrach = Bartoli, Adolfo, (ed.), 1868. Il Libro di Sidrach. Testo inedito del secolo XIV. Parte prima (testo). Bologna: Romagnoli.

Marchionne di Coppo, Cronaca fiorentina = Rodolico, Niccolò, (ed.), 1903. Cronaca Fiorentina di Marchionne di Coppo Stefani. Rerum Italicarum Scriptores, vol. XXX. Città di Castello: Lapi.

Metaura d'Aristotile volgarizzata = Librandi, Rita, (ed.), 1995. La Metaura D'Aristotile. Volgarizzamento Fiorentino Anonimo del XIV secolo. Vols 1-2. (Text: vol. 1, 157-328).

Naples: Liguori.

OVI (Opera del Vocabolario Italiano). http:www.ovi.cnr.it (accessed 30 April 2021)

Percivalle Doria = Come lo giorno quand'è dal maitino/canzone. In ContINI, GIANFRAnco, (ed.), 1962. Poeti del Duecento, 161-163. Naples: Ricciardi.

Petrarca, Canzoniere $=$ Contini, Gianfranco, (ed.), 1964. Petrarca, Francesco. Canzoniere. Turin: Einaudi.

Ricette d'un libro di cucina = Morpurgo, Salomone, (ed.), 1890. LVII Ricette d'un libro di cucina del buon secolo della lingua. Bologna: Zanichelli.

Sacchetti, Rime = Chiari Alberto, (ed.), 1936. Sacchetti, Franco. /l Libro delle Rime. Bari: Laterza. Tavola ritonda o l'Istoria di ... = Polidori, Luigi, 1864. La Tavola Ritonda o l'Istoria di Tristano. Bologna: Romagnoli.

Tristano Ricc. $=$ Heijkant, Marie J. (ed.), 1991. Tristano Riccardiano. Rome: Carocci. 


\section{Old French}

Altfranzösischen Wörterbuch = Bluhmenthal, Peter \& Achim Stein. 2002. Tobler-Lommatzsch: Altfranzösisches Wörterbuch. Stuttgart: Steiner.

Bre. $=$ Le Voyage de Saint Brendan. Ruhe, Ernstpeter (ed.), 1977. Le Voyage de Saint Brendan. Munich: Fink.

$D M F=$ ATILF (CNRS, Université Nancy 2). Dictionnaire de Moyen Français 2009. Nancy. http:// www.atilf.fr (accessed 30 April 2021).

DMF1 = ATILF (CNRS, Université Nancy 2). Base de Lexique de Moyen Français (DMF1). Nancy. http://www.atilf.fr (accessed 30 April 2021).

Frantext $=$ ATILF (CNRS, Université Nancy 2). Base Textuelle de Frantext. Nancy. http://www. frantext.fr (accessed 30 April 2021).

Gui. = Guillaume d'Angleterre. Klüppelholz, Heinz. 1987. Guillaume d'Angleterre. Munich: Fink. Lanc. = Lancelot. Jauss-Meyer, Helga (ed.), 1974. Lancelot. Munich: Fink.

NCA = Stein, Achim, Pierre Kunstmann \& Martin-D. Gleßgen. Nouveau Corpus d'Amsterdam. Corpus Informatique de Textes Littéraires d'Ancien Français (cs. 1150-1350), établi par Anthonij Dees (Amsterdam 1987), remanié par Achim Stein, Pierre Kunstmann et Martin-D. Gleßgen. Stuttgart: Institut für Linguistik \& Romanistik.

Rol. = Chanson de Roland. Steinsieck, Wolf (ed.), 1999. Das Altfranzösische Rolandslied . Stuttgart: Reclam.

Thè. = Roman de Thèbe. Olef-Krafft, Felicitas. 2002. Roman de Thèbes. Munich: Fink.

$T L F i=$ ATILF (CNRS, Université Nancy 2). Trésor de la Langue Française Informatisé. Nancy. http://www.atilf.fr (accessed 30 April 2021). 